\title{
Wojciech Stanisław Chrościński (ok. 1660-po 1733) - człowiek i dzieło
}

„Na przełomie wieków XVII-go i XVIII-go żył i wiele tworzył Wojciech Stanisław Chrościński, poeta, o którym dziś mało kto pamięta, i którym dziś nikt się prawie nie zajmuje. A jednak z wielu względów wart on i zajęcia się i pamięci”; „[...] poeta zdolny i niesłusznie zapomniany, a co gorsza, lekceważony” -

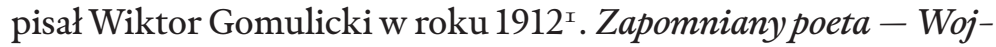
ciech Stanisław Chrościński ${ }^{2}$, tak zatytułowała z kolei swój artykuł, dokładnie sześćdziesiąt lat później, Krystyna Siekierska, będąca również autorką monografii poświęconej charakterystyce języka poety: Jezyk Wojciecha Stanistawa Chrościńskiego. Studium mazowieckiejpolszczyzny z przełomu XVII $i$ XVIII wieku?.

Chociaż od opublikowania prac Siekierskiej upłynęło nieco czasu, to jednak wyrażone przez badaczkę stwierdzenie, że twórczości Chrościńskiego poświęcono mało uwagi pozostaje w zasadzie nadal aktualne. Wspomina się go niekiedy w podręcznikach historii literatury, niektórych opracowaniach dotyczących piśmiennictwa przełomu XVII i XVIII wieku, tymczasem, jak zauważa badaczka, „należał za swego życia i krótko po śmierci do pisarzy bardzo popularnych" ${ }^{4}$. Inicjatywy badawcze Jerzego Starnawskiego ${ }^{5}$, Janiny Janas ${ }^{6}$, Magdaleny Krzyszto-

I W. Gomulicki, Kłosy zpolskiej nizey, Warszawa 1912, s. 12, 264.

${ }^{2}$ K. Siekierska, Zapomniany poeta - Wojciech Stanistaw Cbrościński, „Poradnik Językowy” 1972, nr 3.

3 K. Siekierska, Język Wojciecha Stanistawa Cbrościńskiego. Studium mazowieckiejpolszczyzny z przełomu XVII i XVIII wieku, Wrocław 1974.

${ }_{4}^{4}$ K. Siekierska, Zapomniany poeta, s. 133.

5 J. Starnawski, Nad tekstem osiemnastowiecznego poematu o Józefie. (Poprawki i uzupetnienia), w: Miscellanea staropolskie, red. T. Ulewicz, t. 5, Wroclaw 1980, s. 257-290.

6 J. Janas, Ojczysta ,foza” i , maniera” w języku ,Rozmów listownych” Wojciecha Stanistawa Cbrościńskiego, „Barok” 1995, nr 2, s. 159-171. 
fik $^{7}$ i Marka Prejsa ${ }^{8}$, koncentrujące uwagę na wybranych utworach autora, stanowią odosobnione, jeżeli chodzi o bardziej wnikliwą analizę jego dzieł, dokonania.

Dowodem niegdysiejszej popularności Chrościńskiego są, zdaniem Siekierskiej, liczne wydania jego utworów w wieku XVII i XVIII oraz znajdujące się w bibliotekach kopie rękopiśmienne ${ }^{9}$. Analizując językową stronę dzieł autora, badaczka konstatuje: „Twórczość Wojciecha Chrościńskiego obok niewątpliwych wartości literackich - dziś zapomnianych i nie docenianych - zawiera olbrzymi i cenny materiał do badań językowych" ${ }^{\text {Io }}$.

Przekonanie o tym, że twórczość Chrościńskiego cieszyła się życzliwym przyjęciem i powodzeniem u jego współczesnych oraz że warta jest dokładniejszego poznania podzielał już przy końcu XIX wieku Aleksander Brückner, który pisał: „Chrościński zasługuje ze wszech miar na bliższe zbadanie swej spuścizny literackiej, przewyższając i stylem i liczbą prac i ich rozmaitością współczesnych pisarzy, Ustrzyckiego, Bardzińskiego, Wadowskiego i innych, kończąc godnie szereg, w którym błyszczą imiona Twardowskiego i Potockiego" II. Chrościński to zdaniem Brücknera „najznakomitszy saskich czasów poeta” ${ }^{\text {I2 }}$, który swoimi utworami wyszedł niejako naprzeciw gustom i literackim upodobaniom czytelników swego czasu. Jak zauważa badacz: „Pisarz to chętnie czytany, o czem już liczne odpisy jego dzieł świadczyły” ${ }^{\text {I }}$.

7 M. Krzysztofik, Od Biblii do literatury. Siedemnastowieczne dzieła literackie z ksiag Starego Testamentu, Kraków 2003 (rozdz. Wojciech Stanistaw Cbrościnski „Job cierpiacy”, s. 213-274, oraz Wojciech Stanisław Chrościnski „Treny Hieremiaszowe”, s. 275-308).

${ }^{8}$ M. Prejs, Oralność i mnemonika. Późny barok w kulturze polskiej, Warszawa 2009 (rozdz. Psalm jako formuła pamięci).

9 Ibidem, s. 133. Na dowód tego przywołuje autorka fakt, że w Bibliotece Ossolineum we Wrocławiu, oprócz autografu (sygn. 5319/I), znajdują się cztery kopie dzieła Chrościńskiego Józef od braci przedany - o sygn. 864/I, 681/I, 940/I, 1837/I, w Bibliotece Narodowej kopia o sygn. 6827/III, a w Bibliotece Uniwersytetu Warszawskiego egzemplarz wydania z roku 1745 o sygn. 4.19.7.70.

то K. Siekierska, Język Wojciecha Stanistawa Chrościńskiego, s. 12.

II A. Brückner, [rec.] Chrościński W.St., Lament strapionej ojczyzny... [nieznany wiersz wydał dr B. Erzepki, Poznań 1895. Odbitka z „Roczników Towarzystwa Przyjaciół Nauk Poznańskiego” 1895, t. 21, s. 26], „Kwartalnik Historyczny" 1896 , z. 1, s. 371. s. 21.

I2 A. Brückner, Z dziejów języka polskiego. Studia i szkice, Lwów 1908,

I3 A. Brückner, Dzieje kultury polskiej, t. 2, Czasy nowsze do roku 1831, Kraków 1931, s. 105. 
Niegdysiejszą popularność autora potwierdza też informacja zawarta w Encyklopedii Powszechnej Ultima Thule: „Poeta płodny, w swoim czasie ceniony, dla nas dzisiaj jest charakterystycznym okazem poezji z ostatniego okresu baroku, na przełomie wieku XVII i epoki saskiej" I4. Tadeusz Mikulski z kolei przedstawiając sylwetkę Chrościńskiego zauważał: „Jako autor przepisywany chętnie i czytany długo (ostatni przedruk z r. 1794), mylony nieraz z wybitnymi poetami epoki (Kochowski, Lubomirski), zasłużył na pochwałę Załuskiego oraz wywołał szereg przeróbek i naśladownictw (Drużbacka, Jabłonowski)" ${ }^{5}$.

Zanim przyjrzymy się formułowanym przez innych badaczy ocenom twórczości Chrościńskiego, zrekonstruujmy na podstawie zachowanych wiadomości najważniejsze wydarzenia $\mathrm{z}$ jego życia ${ }^{16}$ i dokonajmy zestawienia jego utworów.

Chrościński urodził się $\mathrm{w}$ Warszawie $\mathrm{w}$ rodzinie mieszczańskiej. Nie ma jednoznaczności stanowisk co do daty urodzin poety. Wskazuje się czas około roku $1660^{17}$ albo też około roku $1665^{18}$. Dzieciństwo i młodość spędził najpewniej w stolicy. Wcześnie zaciągnął się w służbę u Andrzeja Modrzewskiego, podskarbiego i pułkownika koronnego, uczestnicząc przy jego boku w wyprawie Jana III Sobieskiego pod Wiedeń. Służba nie trwała długo, ponieważ Modrzewski zginął w bitwie wiedeńskiej:

Ledwom się tylko poznał z tobą Panie

Dość krótką chwilę, będąc przy twym boku

Aż w powitaniu jak nagłe rozstanie ${ }^{\text {I9 }}$.

${ }_{4} 4$ Encyklopedia Powszechna Ultima Thule, t. 2, Warszawa 1928, s. 409.

I5 T. Mikulski, Rzeczy staropolskie, wstęp W. Weintraub, Wrocław 1964, s. 358.

${ }^{\text {I }}$ „O życiu Wojciecha Stanisława Chrościńskiego mamy dotychczas niejasne dane", pisze W. Jędrychowski, Próba rekonstrukcji biografii Wojciecha Stanistawa Chrościńskiego, „Ruch Literacki” 1930, nr 7, s. 215.

${ }_{7}$ Zob. K. Siekierska, Zapomniany poeta; Dawni pisarze polscy: od początków piśmiennictwa do Młodej Polski. Przewodnik biograficzny i bibliograficzny, t. 1 (A-H), koordynator całości R. Loth, Warszawa 2000, s. 169.

I8 Zob. Bibliografia literatury polskiej Nowy Korbut. Piśmiennictwo staropolskie, t. 2, Warszawa 1964, s. 83; „O życiu Chrościńskiego - pisze S. Spławiński (,Farsalia” Lukana w przekładach polskich XVII wieku, Kraków 1929, s. 11) posiadamy, jak dotąd, bardzo skąpe wiadomości. Nie znamy daty jego urodzenia, nie znamy dokładnie daty śmierci”.

I9 W.S. Chrościński, Trąba wiekopomnej sławy i pamięci najjaśniejszego i niezweyciężonego Jana III, Warszawa 1684, strofa 38. 
Chrościńskiemu przyszło eskortować jego ciało do Polski ${ }^{20}$, "wieść go konwojem spod Wiednia do domu” ${ }^{21}$. Następny etap życia poety wyznacza pobyt na dworze biskupa warmińskiego Michała Radziejowskiego, w którego osobie znalazł życzliwego opiekuna i któremu też zadedykował swój pierwszy utwór literacki - poemat Traba wiekopomnej stawy i pamięci najjaśniejszego i niezreyciężonego Jana III... wydany w Warszawie w roku 1684. Wiosną 1685 roku otrzymał tytuł sekretarza królewskiego i powierzono mu kierownictwo kancelarii królewskiej. Aktem z dnia 25 maja tegoż roku król Jan III Sobieski nadał mu tytuł szlachecki z herbem Junosza ${ }^{22}$. W uzasadnieniu nobilitacji wskazano na zasługi żołnierskie, zalety urzędnicze i osiągnięcia w pracy literackiej Chrościńskiego (et arte et Marte probata virtus) ${ }^{23}$. Przez krótki czas pełnił też Chrościński obowiązki zwierzchnika nad puszkarzami w Tczewie ${ }^{24}$.

W latach 1685-1696 wiódł Chrościński spokojny żywot urzędnika królewskiego, oddając się równocześnie twórczości literackiej ${ }^{25}$. W roku $1690^{26}$ stabilizuje się też jego życie oso-

${ }^{20}$ T. Mikulski, Wojciech Stanistaw Chrościński, w: Rzeczyy staropolskie, s. 356 (przedruk z: Polski Słownik Biograficzny, t. 3, Kraków 1937, s. 453-454). O śmierci A. Modrzewskiego donosi Chrościński w liście do wdowy - Urszuli z Krasickich Modrzewskiej, kasztelanki przemyskiej, pisanym w Przeworsku, po drodze z Krakowa do Jarosławia, kilka dni po bitwie wiedeńskiej - 29 października 1683 roku. List ten stanowi niezwykle sugestywny opis końca życia podskarbiego. Opublikował go F. Friedman, który zauważa, że list jest „odpisem z oryginału, sporządzonym - prawdopodobnie własnoręcznie” (F. Friedman, Nieznana relacja o batalii wiedeńskiej, „Przegląd Historyczno-Wojskowy” 1935, t. 7, s. 135). Zawarł w nim Chrościński ponadto żywą, plastyczną i bezpośrednią relację o bitwie wiedeńskiej i realiach obozowego życia oraz okolicznościach śmierci A. Modrzewskiego. Jak zauważa K. Targosz (Jan III Sobieski mecenasem nauk $i$ uczonych, Wrocław 1991, s. 87), „gdyby po Chrościńskim przetrwało więcej listów i gdyby pisywał on pamiętniki, mógłby niewątpliwie w barokowej polskiej prozie zająć godne miejsce obok Sobieskiego i Paska”.

${ }^{21}$ W.S. Chrościński, Trąa wiekopomnej starey, strofa 37.

${ }^{22}$ Ibidem. Herb ten należy do najstarszych herbów polskich i przedstawia srebrnego barana na czerwonym polu. Zob. Polska encyklopedia szlachecka, t. 3, Warszawa 1935, s. 319.

${ }_{23}$ T. Mikulski, op.cit., s. 356. „W zbiorze praw i przywilejów czytamy: «Przychylając się do prawa i zwyczaju za rekomendacją Wielmożnych Hetmanów obojga narodów ludzi w wojskach dobrze zasłużonych... ST. Chrościńskiego... cum PROLE, które mają i mieć będą do prerogatywy stanu szlacheckiego za zgodą wszech stanów przypuszczamy»" (J. Jędrychowski, op.cit., s. 216).

${ }_{24}$ Bibliografia literatury polskiej Nowy Korbut, op.cit., s. 8.

25 K. Siekierska, Język Wojciecha Stanistawa Chrościńskiego, s. 6. „Na dworze królewskim cieszył się Chrościński dużym poważaniem i otaczała go sława wielkiej uczoności. Król bardzo chętnie przechadzał się razem z nim po parku wilanowskim i słuchał «poważnych rytmów Chrościńskiego»". Zaufaniem królewskim cieszył się poeta dość dużym. Nic też dziwnego, że był mu oddany i wielbił króla w utworach" (J. Jędrychowski, op.cit., s. 216).

${ }^{26}$ J. Jędrychowski (op.cit., s. 216) opowiada się za rokiem 1686. 
biste - żeni się z Agnieszką Woodówną. Zawarcie małżeństwa przyczyniło się również w znacznym stopniu do poprawy warunków materialnych. Do posiadanych już przez poetę dóbr w ziemi sochaczewskiej (Żukowa i Dzięgielowa) doszły dalsze posiadłości - Wola Szydłowiecka, Humin, Wieś Bolimowska, uzupełnione później o wieś Wielką Wolę, którą otrzymał z nadania królewskiego ${ }^{27}$.

Koniec kariery dworskiej nastąpił wraz ze śmiercią króla Jana III Sobieskiego. Śmierć monarchy była dla związanego z dworem Sobieskich Chrościńskiego wielkim wstrząsem. Oddał się na służbę królewicza - Jakuba, widząc w nim naturalnego następcę tronu. Jednak klęska domu Sobieskich, wybuchające zamieszki i ogólnie panująca atmosfera niechęci i wrogości wobec zwolenników rodu zmarłego króla sprawiły, że poeta opuścił Warszawę i schronił się we wsi Blanowice pod Częstochową ${ }^{28}$. Tam, w roku 1709, zmarła mu żona ${ }^{29}$. Sytuację doświadczanego nieszczęścia i związanego z nim kryzysu ideowego zawarł w Trenach żałob$n y c b^{\circ}$. Około roku 1711 Chrościński żeni się powtórnie z Apolonią Otwinowską, „z której liczne zostawił potomstwo" ${ }^{\mathrm{I}}$, dziedziczką wsi Błeszno w powiecie lelowskim, osady leżącej między Częstochową a Oławą ${ }^{32}$. Ta ostatnia staje się, po klęsce politycznej i nieudanej elekcji, siedzibą rodu Sobieskich 33 .

Jak zauważa Siekierska, „w dotychczasowych opracowaniach nie było zgodności co do przypuszczalnej daty śmierci poety.

27 T. Mikulski, op.cit., s. 357.

${ }_{28}$ K. Siekierska, Język Wojciecha Stanisława Cbrościńskiego, s. 7.

29 J. Jędrychowski (op.cit., s. 217) wskazuje jako datę śmierci żony Chrościńskiego rok 1703. Pisze: „Datę tę ustaliłem w następujący sposób: W Trenach mamy wzmiankę, że żona Agnieszka zmarła w Blanowicach dnia 12 sierpnia. Dzień ten przypadał w poniedziałek. Zatem istnieją dwie możliwe daty: 1697 i 1703. Prawdziwa jest jednak druga. Wiemy, że poeta żyje z żoną lat 19, wobec tego data 1703 zbiega się z nobilitacją 1685. [...] Ostatnie jej chwile opisał w Trenach. Tam też czytamy: O wschodzie stońca w sam dzień śweiętej Klary/ Pozbyłaś życia i poszłaś na mary. Przyczyna choroby przedstawia się dość zagadkowo: Los ojczystej zamieszki / O szwank cięprzywiódt ciężki. / Stąd się kalectwo wzięło przy chorobie/ I pomýlitaś we dwóch lat o grobie".

$3^{\circ}$ W.S. Chrościński, Treny żałobne [...] napisane [...] Agnieszce Chruścińskiej $[$...] od osierociałego jej matżonka, Częstochowa 1709. Egz. BUW 4.19.7.62. Zob. A. Nowicka-Jeżowa, Siedemnastowieczna poezja funeralna w kregu tradycji renesansowej. Przeksztatcenia i przewartościowania, w: Przełom wieków XVI $i$ XVII w literaturze i kulturze polskiej, red. B. Otwinowska, J. Pelc, Wrocław 1984, s. 196, 199, 200, 205.

${ }^{3}$ Encyklopedia Powszechna, t. 5, nakład, druk, własność S. Orgelbrand, Warszawa 1869, s. 522.

$3^{2}$ J.S. Bandtkie, Rozprawa o Wojciechu Stanistawie Chrościńskim, „Rocznik Towarzystwa Naukowego z Uniwersytetem Krakowskim Połączonego” 1826, t. 11, s. 168 .

33 Ibidem. 
Przyjmowane były trzy możliwości: 1) ok. roku 1717, np. Bentkowski w Encyklopedii poweszechnej Orgelbranda; 2) po r. 1722 Korbut, także Nowy Korbut; 3) w pierwszych latach panowania Augusta III, a więc po r. 1733 - I. Krasicki oraz z nowszych opracowań WEP [Wielka Encyklopedia Powszechna - L.T.]. Odnalezione listy wykluczają dwie pierwsze daty. W tej sytuacji wiarygodna staje się wersja Krasickiego i jest prawdopodobne, że Chrościński dożył do początków panowania Augusta III; w chwili śmierci miałby około 73 lat (Krasicki pisze, że umarł w sędziwym wieku)" ${ }^{34}$.

Debiutem literackim Chrościńskiego był, napisany po wpływem przeżyć związanych z odsieczą wiedeńską, panegiryczny poemat w 119 oktawach na cześć zwycięzcy - króla Jana III Sobieskiego Traba wiekopomnej sławy i pamięci Najjaśniejszego i niezreyciężonego Jana III z Bożej taski Króla Polskiego, Wielkiego Ksiażęcia Litewskiego, Ruskiego, Pruskiego, Mazowieckiego, Inflantskiego, Podolskiego, Wobyńskiego, Kijowskiego, Smoleńskiego, Siewierskiego $i$ Czernichowskiego. Wiedeńska $i$ Parkańska oraz z Turczyna Victoria opiewajaca, Roku Pańskiego 1684. Na widok pokazana ${ }^{35}$, wydany w Warszawie, w Drukarni Karola Ferdy-

${ }^{34}$ K. Siekierska, Język Wojciecha Stanistawa Chrościńskiego, s. 10. Argumentem za datowaniem śmierci Chrościńskiego na lata trzydzieste XVIII wieku są według Siekierskiej jego odnalezione listy - autografy, z których ostatni napisany został 26 października 1729 roku. Por. K. Siekierska, Zapomniany poeta, s. 133. Bibliografia literatury polskiej Nowy Korbut (op.cit.) podaje informację, że poeta „zmarł po 1722”. Taką samą informację znajdujemy w antologii Poeci polskiego baroku, oprac. J. Sokołowska, K. Żukowska, t. 2, Warszawa 1965, s. 432. W Stowniku jezzyka polskiego XVII i 1. połowy XVIII wieku (t. 1, z. 1, Kraków 1999, s. LXXVII) w Biogramach pisarzy polskich oraz thumaczy dziet obcojezycznych zawartych w kanonie źródet „Stownika” znajdujemy wiadomość, że Chrościński zmarł po 1729 roku. Natomiast w opracowaniu Dawni pisarze polscy (op.cit., s. 169) czytamy: „zmarł ok. 1722 (po 1733?)”. Informację o tym, że Chrościński dożył późnej starości oprócz I. Krasickiego (Dzieła, t. 3, Warszawa 1829 , s. 166), który pisał: „w wiejskiej spokojności życia w wieku sędziwym dokonał, na początku panowania Augusta III", znajdujemy także u I. Chodynickiego (Dykcjonarz uczonycb Polaków, t. 1, Lwów 1833, s. 75): „w sędziwej starości zakończył swoje życie w początku panowania Augusta III króla”, K.W. Wóycickiego (Historia literatury polskiej w zarysach, t. 3, Warszawa 1845, s. 191): „umarł na początku panowania Augusta III”, S. Spławińskiego (op.cit., s. 12): „umiera w sędziwym wieku na początku panowania Augusta III”. Jędrychowski (op.cit., s. 215-216) zaś zauważa: „Jeżeli przyjmiemy zwykle podawaną datę śmierci jako rok 1717, wtedy opierając się na słowach Krasickiego, że „w spokojności życia w wieku sędziwym dokonał”, oraz na słowach Janockiego: „regnante Augusto tertio: nonagenario maior, fato concensit”, możemy ustalić przypuszczalną datę urodzin. Jednakowoż 1717 r. wydaje mi się datą trochę za wczesną tym bardziej, że jest bardzo odległą od początków panowania Augusta III, t.j. od 1733 r.”.

35 Egz. Ossolineum XVII-6301-III. Zob. też na temat Traby...: K.M. Górski, Pisma literackie. Z badań nad literatura polska XVII $i$ XVIII wieku, Warszawa 1913, s. 142-150; K. Targosz, op.cit., s. 87 . Tytuły oraz cytaty z dzieł 


\title{
nanda Schreibera ${ }^{6}$. Utwór zadedykował autor biskupowi war- mińskiemu Michałowi Radziejowskiemu, kuzynowi Jana III37, który stał się jego protektorem:
}

\author{
Przyimże zatym Kamenę ubogą, \\ Co się na Twoim wszcząć miała pokoju. \\ Teraz przez swoją niefortunę srogą \\ Już oddalona z progu i podwoiu.
}

Chrościńskiego podaję na ogół z pierwodruków, transkrybując teksty zgodnie z powszechnie przyjętymi Zasadami wydawania tekstów staropolskich. Projekt, oprac. K. Górski i in., Wrocław 1955. Obok Chrościńskiego w czasach saskich zwycięstwo króla Jana III Sobieskiego sławili także m.in. J. Ustrzycki dziełem Sobiesciados seu de laudibus Joannie Magni libri quinque oraz pochodzący z Wielkopolski pijar o imieniu zakonnym Jan Damascen od Matki Bożej, którego historyk pijarów Sz. Bielski rozpoznał jako niejakiego Kalińskiego. Poemat Kalińskiego to wydany w Warszawie w roku 1717: Viennis memorabilia Turcarum obsidione felicissimo Leopoldi I imperio, insigni Joannis III Victoria, Principium S. R. I. auxiliis, ducum procerumque Poloniae fortitudine, Asiae editio gloriosa... Zob. P. Chmielowski, Sobieski w epopei z czasów saskich, „Ateneum” 1883, t. 4, s. 152-173. Wiktoria wiedeńska odbiła się szerokim echem w piśmiennictwie nie tylko polskim, ale także innych narodów europejskich. Wpisywała się ona w nurt literatury o Sobieskim jako genialnym wodzu i obrońcy chrześcijaństwa. Zob. J. Bystroń, Rok 1683 w literaturze niemieckiej, Poznań 1883; M. Brehmer, Toskańskie echa zwycięstwa pod Wiedniem, Kraków 1934; J. Śliziński, Jan III Sobieski w literaturze narodów Europy, Warszawa 1979; B. Klimaszewski, Jan III Sobieski w literaturze polskiej $i$ zachodnioeuropejskiej XVII $i$ XVIII wieku, Kraków 1983. Zob. także: J. Krzyżanowski, Jan III Sobieski w tradycji anegdotycznej, w: idem, Paralele. Studia porównawcze z pogranicza literatury i folkloru, Warszawa 1977, s. 381-392. K. Maliszewski, autor wstępu i komentarzy do wydania Janiny, relacji o Wiktorii Wiedeńskiej pióra J.K. Rubinkowskiego z 1739 roku, zauważa ponadto, że „Wiktorię Wiedeńską i jej bohatera opiewano [...] także na kontynencie amerykańskim. Rzecz charakterystyczna, że nawet u samych Turków zwycięstwo chrześcijańskiego monarchy nie zostało bez oddźwięku” (J.K. Rubinkowski, Relacja o Wiktorii Wiedeńskiej 1683 roku [fragment JANI$N Y$, wydał z oryginału, wstępem i komentarzami opatrzył K. Maliszewski, Warszawa 1983, s. 8). Zob. także Kara Mustafa pod Wiedniem. Źródła muzutmańskie do dziejów wyprawy wiedeńskiej 1683 roku, z tureckiego przeł., oprac. Z. Abrahamowicz, Kraków 1973. W opracowaniu Literacka infamia Sobieskiego, „Ruch Literacki” 1983, z. 5, K. Maliszewski zwraca uwagę na to, że w zalewie utworów panegirycznych poświęconych odsieczy wiedeńskiej i Sobieskiemu, których liczba „w samym roku 1683 przekroczyła sumę dwustu tytułów” (s. 343), pojawiały się także łacińskie i polskie epigramaty, paszkwile, pamflety i satyry o wyraźnie negatywnym stosunku wobec króla.

${ }_{36}$ Poemat został w tym samym roku ogłoszony w Warszawie po łacinie jako Tuba vocalis famae, ac aeuiternae memoriae Serenissimi ac Invictissimi Joannis III, Deigratia Regis Poloniae, Magni Ducis Lithuaniae, Russie, Prusiae, Masoviae, Samogitiae, Volbyniae, Kiiouiae, Smolensciae, Seueriae Czernichouiaeque. Ad Viennam, et Parkanum Samul, de Turcis obtentam victoriam buccinans. Anno Domini 1684. repraesentata. Zob. J.S. Bandtkie, Dodatek do rozprawy V. Tomu XL. Reczników Towarzystwa Naukowego, ,Rocznik Towarzystwa Naukowego z Uniwersytetem Krakowskim Połączonego”, t. XIV, Kraków 1831, s. 28-37.

37 K. Targosz, op.cit., s. 88. 
Autor nie podaje swojego nazwiska, ale skrywa się za sza$\operatorname{radac}^{38}$ :

Prymas gnieźnieński dał mi imię swoje

Infułat drugie, Krakowskie oboje,

W leśnym nazwisku widomie wynika,

Chcesz wiedzieć, ktom jest, ta mię gadka tyka.

Poemat rozpoczyna się następującą strofą:

Milczcie już wieki i mrukliwe czasy,

Niemotą wieczną zawierajcie usta;

Nie tłoczcie więcej pism drukarskie prasy

Biblioteka niech wakuje pusta,

Bo sam dźwięk sławy na te się zapasy

Odważył, aby Polskiego Augusta

Światu ogłosił wespół z jego czyny

Słodkim peanem trąby swej jedyny.

W dalszej jego części, pisząc o królu Janie III Sobieskim, wykorzystuje autor mitologiczne i historyczne porównania, nazywając władcę polskim Alcydą, Romulusem, Herkulesem, Atlasem, Numą i Pompejuszem:

O, urodzony Polski Herkulesie

I Chrześcijaństwa całego pieszczoto!

Trąba wielkości Twych moja nie zniesie

I próżnym duchem pasuje się o to.

Przecięż w nadzieję łask Twych ośmielę się,

Wiedząc, że jako Jubiler swe złoto

Nad się zacniejsze glansuje przystojniej,

Tak ja Twe Imię trąbą zabrzmię strojniej.

Odwrocicielu Boskiego zapału

I naszych wieków rozkoszy jedyna,

Upadającej już, już niepomału

$3^{8}$ Nierzadki to sposób zaszyfrowywania własnego nazwiska przez autorów epoki baroku. Wspomnijmy w tym miejscu chociażby kartę tytułową rękopisu Wizerunku złocistej przyjaźnia zdrady, na której umieszczony został dwuwiersz zatytułowany Autor: „Imię ma z raju, SKI ogon przezwiska,/ ROK wspaczni głową, CZYN w środek się wciska”. Pod postacią logogryfu, rodzaju literackiej zagadki, polegającej na rozbiciu wyrazu na sylaby ukryte w wierszu tak, by czytelnik mógł złożyć całe słowo, ukrył się Adam Korczyński. Zob. A. Korczyński, Wizerunk złocistejprzyjaźnią zdrady, wyd. R. Grześkowiak, Warszawa 2000. 
Ojczyzny, której Wschód ciężki dopina,

A ona, chociaż bez murów i wału,

Za twym powodem przecię się odcina,

Możny Athlancie, łamiąc pierwsze lody

I w dalsze $\mathrm{z}$ tobą ośmielona brody 39 .

Walkę chrześcijan z mahometanami ujmuje jako przeciwstawienie słońca i księżyca, światłości i ciemności. Symbolem Polaków są orły, Turków - sowy i puchacze.

Poświęcając się własnej twórczości literackiej, Chrościński podejmuje się zarazem pracy przekładowej, tłumaczeń z literatury rzymskiej. Pierwszym dokonaniem w tym zakresie jest poetycki przekład Heroides sive epistulae Owidiusza, który zatytułuje Riposta, albo raczej żalu i skargi petna Amoratek korespondencja częścia niewdzięcznikami Amaryuszów niektórych cześcia też wajemnych nagrodzona afektem i zadedykuje swojej narzeczonej Agnieszce Woodownie ${ }^{40}$.

W 1690 roku ogłasza Chrościński drukiem thumaczenie Farsalii Lukana. Pełny tytuł dzieła brzmi: Pharsalia po polsku przethumaczonego Lukana albo raczej wojna domowa między Pompejuszem a Cezarem rzymskimi wodzami z tacińskiego na ojczysty jezzyk przez Wojciecha Chrościńskiego J. K. Mci Sekretarza w Roku Pańskim 1690 przetożona. Drukowano w Oliwskim Klasztorze przez Jana Jakuba Textora ${ }^{4}$. Przekład zadedykował królowi Janowi III. W liście dedykacyjnym poprzedzającym Farsalię Chrościński w następujący sposób charakteryzuje swoją pracę jako thumacza:

39 W.S. Chrościński, Trąa wiekopomnej stawy, w: Helikon sarmacki, watki itematy polskiejpoezji barokowej, oprac. A. Vincenz, M. Malicki, Wrocław 1989, s. 366-368.

$4^{\circ}$ Egz. Ossolineum sygn. XVII-6046, XVII-6047, XVII-6048. Rękopis, kopia egz. Ossolineum 679/I.

${ }^{4}$ I Egz. Biblioteki Kórnickiej PAN sygn. 3585. Egz. Ossolineum sygn. XVII-19106, XVII-19107, XVII-16461. Tłumaczenie obejmuje dzieło Lukana (10 ksiąg) oraz Suplement (7 ksiag) napisany heksametrem łacińskim w XVII wieku przez Thomasa Maya, który przełożył też, w tym samym czasie, Farsalię na język angielski. Dzieło liczy 350 stron plus 95 stron Suplementu. Por. S. Spławiński, „Farsalia” w przekładzie Wojciecha St. Chrościnskiego, w: „Farsalia” Lukana w przekładach polskich, s. 14). W 1691 roku ukazuje się, także w Oliwie, przekład Farsalii dokonany przez dominikanina J.A. Bardzińskiego. Z kolei w latach 1685-1692 powstało thumaczenie (czy może adaptacja) innego dominikanina T. Nargielewicza, które pozostało w rękopisie (zob. S. Nieznanowski, Staropolska epopeja bistoryczna. Ksztaltowanie siępojęcia, drogi rozwoju, w: Problemy literatury staropolskiej, S. 1, red. J. Pelc, Wrocław 1972, s. 315). Zbieżność dat dowodzi, że u schyłku XVII wieku Lukan stał się bardzo modny. 
Na kształt ojczystej maniery i fozy ${ }^{42}$

Słowiańską muzą w polskim Helikonie

Świeżo z łacińskiej przełożywszy prozy...

W 1693 roku w tej samej oficynie drukarskiej ukazuje się Pharsaliej albo raczej wojny domowej rzymskiej od zabicia w senacie Juliusza Cezara między dwiema stronami: jednej o wolność drugiej pod pretekstem zemsty jego zaboju o nabycie państwa czyniacymi. Ażdo ostatniej Antoniusza pod Actium z Augustem rozprawy kontynuacja z różnych tacińskich historyków Rzymskich dzieje opisujacych. W dziesięć ksiag zebrana przez Wojciecha Stanistawa Chrościńskiego J. K. Mci. Sekretarza w Roku Pańskim 169343. Jest to kompilacja mająca być jakby dalszą częścią tłumaczenia sprzed trzech lat. Dzieło poprzedził Przedmowa, w której czytamy:

W początku tej wojny, którą był przedsięwziął Lukanus poeta wszytkę, aż do objęcia dziedzicznego państwa, wierszem swoim skończyć, jest wzmianka o tych dziejach i transakcjach, co się w tym drugim tomie moim zawierają, skąd, żeby ni było opus imperfectum civilium bellorum, pozbierałem $\mathrm{z}$ różnych autorów, rzymskie dzieje opisujących, samę treść rerum gestarum i, nie bawiąc się żadnemi dygresjami, poetyckiemi, jakowe się znajdują w Farsalijej Lukana, vim historiae wyraziłem, aż do czterdziestego wtórego roku panowania Augusta Cesarza, kiedy się Chrystus Pan i Zbawiciel nasz urodził, dociągnąwszy zamierzonej pierwszego Autora intencyjej, gdyż na ten czas, po uspokojeniu wszystkich i obcych, i domowych wojen, Kościół Janusa na znak wielkiego po całym świecie pokoju zamknięty był w Rzymie ${ }^{44}$.

Chrościński użył jako miary wierszowej oktawy:

formy trudnej i wymagającej od twórcy wielkiej kultury artystycznej i wyrobionego smaku, a więc zalet, jakich darmo szukać w Polsce u schyłku XVII w. Z góry tedy wolno się spodziewać, że wybór ten będzie niefortunny. Tłumacz rozwadnia dla rymu treść oryginału, który sam przez się nie grzeszy zbytnią zwięzłością wyrazu; na przekładzie zaciążyło to fatalnie. Charakterystyczna dla przeżywa-

$4^{2}$ „Foza” - od włoskiego „foggia”, to forma, kształt zewnętrzny, moda, sposób mówienia, postępowania, ubierania się. W. Meisels, Podręczny stownik polsko-wtoski, t. 1 (A-L), Warszawa 1986, s. 593.

43 Egz. Biblioteki Kórnickiej PAN sygn. 3999. Egz. Ossolineum sygn. XVII-16.462, XVII-16543. Egz. BUW 4.19.1.22. Dzieło liczy 517 stron.

44 Cyt. za: S. Spławiński, op.cit., s. 14. 
jącego się już i wyradzającego baroku gadatliwość jest jedną z najznamienitszych cech przekładu 45 .

Rok $1695{ }^{46}$ jest datą ukazania się drukiem Riposty, czyli dokonanego wcześniej, prawdopodobnie około roku 1689, tłumaczenia Heroid Owidiusza. Chrościński ogłasza rzecz pod tytułem Rozmowy listowne albo raczej wzajemna Heroin Greckich z kawalerami korespondencyja czesścia równym afektem, częścia też niewdziękami nagrodzona przez Wojciecha Stanistawa Chrościńskiego J.K.M. Sekretarza i Pisarza Pokojowego z tacinskich Owidiusza wierszy przethumaczona i do druku w roku 1695 podana ${ }^{47}$. Nieznane jest miejsce wydania dzieła, zadedykowanego królewiczowi Jakubowi Sobieskiemu, w którym Chrościński upatrywał następcę tronu. Tłumaczenie znalazło się na indeksie książek zakazanych $^{4}{ }^{8}$. Fakt ten ilustruje, jak zauważa Hanna Dziechcińska,

przemiany $\mathrm{w}$ odczytywaniu $\mathrm{i}$ interpretowaniu poszczególnych utworów literackich, jakie pojawiały się wraz z upływem czasu... [...] Chrościński w swej twórczości skłaniał się wyraźnie ku wątkom erotyczno-romansowym, wprowadzając je również do dzieł takich jak Józef do Egiptu od braci przedany, gdzie zamieścił epizody takie jak kuszenie Józefa przez Putyfarę. W tych latach jednak erotyki w powieściach nie aprobowano, a więc utwór Wojciecha Chrościńskiego mógł ukazać się drukiem dopiero w pierwszej połowie XVIII wieku, w roku $1733^{49}$.

Na końcu Rozmów znajdują się dwa wiersze związane ze ślubem królewny Teresy Kunegundy z elektorem bawarskim Maksymilianem Emanuelem: przekład, a właściwie parafraza, psalmu Beati omnes, qui piment Dominum, który elektor kazał recytować $\mathrm{w}$ czasie potwierdzenia zaślubin, oraz wiersz noszący tytuł Pożegnanie na obrazku Najświętszej Panny Maryi, które król Jego Mość Jan III jedynej córce swojej królewnie polskiej do Ksią̇ęca

45 Ibidem, s. 15. Spławiński na dowód owego, jak to nazywa, „rozwadniania treści” podaje proporcje: „Farsalia w oryginale liczy 8060 w., przekład 10796”. Następnie bardziej szczegółowo charakteryzuje język i wiersz oraz użyte środki stylistyczne. Zwraca też uwagę na zastosowane przez Chrościńskiego liczne sygnały polonizowania oryginału.

46 Wydanie drugie ukazuje się w roku 1733.

47 Egz. Biblioteki Kórnickiej PAN sygn. 126927, 126944 Def. Egz. Ossolineum sygn. XVII-6046, XVII-6047, XVII-6048. Wydanie z roku 1733: Egz. Biblioteki Kórnickiej PAN sygn. 1587.

$4^{8}$ C. Hernas, Barok, Warszawa 1980, s. 552.

49 H. Dziechcińska, Przesztość i teraźniejszość w kulturze czasów saskich, Warszawa 2007, s. 32. Nie jest to w pełni ścisła informacja, ponieważ datą ukazania się dzieła Chrościńskiego jest rok 1745. 
Jego Mości Elektora Bawarskiego Małżonka swego po odprawionym weselu wyjeżdzajacej własna ręka napisat. Ten drugi przypisywano później samemu królowi. Jednakże to Chrościński przekształcił na polski wiersz dedykację ojcowską napisaną prozą, podobnie jak na łacinę zamienił ją pijar Benedykt od św. Józefa i opublikował rok wcześniej w swoich Lyricorum libri quatuor $5^{\circ}$.

Rozmowy listowne Chrościńskiego zawierają 21 listów Owidiusza oraz następne pięć listów: odpowiedź Ulissesa na list Penelopy, odpowiedź Demofonta do Fyllit, odpowiedź Parysa Ojnone i list Charona do Deifile oraz jej odpowiedź. Badacze charakteryzujący przekład wskazują przede wszystkim na zawarte w nim elementy polonizacyjne, które dotyczą polskich realiów, imion własnych bohaterów, ich zachowań oraz wypowiedzi kształtowanych zgodnie z polską "manierą i fozą" ${ }^{\mathrm{I}}$. O wielkim indywidualizmie poety świadczą liczne neologizmy, które skrzętnie odnotowuje w swoim Stowniku Samuel Bogumił Linde, zazna-

$5^{\circ}$ K. Targosz, op.cit., s. 88. Domysł o autorstwie Sobieskiego uznał za chybiony anonimowy autor: Wiersz przypisany mylnie królowi Sobieskiemu, „Biblioteka Warszawska” 1883, t. 170, s. 481-482. Zob. także: W. Gomulicki, Poeci na tronie polskim, w: Kłosy z polskiej nirey, Warszawa 1912, s. 11-15. Gomulicki (s. 13-14) rozstrzyga rzecz następująco: „Nie ulega żadnej wątpliwości, że autorem Pożegnania jest Chrościński. Byłoby też błędem największym sądzić, że temu sam Sobieski lub ktokolwiek z jego otoczenia zaprzeczał. Nie przeczy też faktowi i wyraźnie w tytule użyte: Król Jegomość własna ręką napisat. Sobieski tak uczynił niezawodnie - ale dlatego tylko, że chciał córce pamiątkę pisma swego zostawić. Ułożył zaś wiersz kto inny, mianowicie „sekretarz i pisarz pokojowy królewski" to jest człowiek, do którego to niejako z urzędu należało. W owym czasie nie tylko król i magnaci, ale i zwykła, nieco zamożniejsza, szlachta we wszelkim pisaniu chętnie wyręczali się „sekretarzami” i „pisarzami”. Zwłaszcza gdy szło o „koncept” rymowany lub nierymowany, o powinszowanie imienin lub urzędu, o toast weselny lub sejmikowy, płatny wyręczyciel zastępował szlachcica, którego sapientia na sprawy ważniejsze była zachowana. Sekretarz - którego zastępował często preceptor dzieci szlacheckich, albo dowcipny „braciszek” z najbliższego klasztoru - układał i pisał nawet listy prywatne, a szlachcic kreślił tylko u spodu niedbale: „Z powinnym afektem W. Pana mego Miłościwego sługa przychylny N. N. ręką swą. [...]”. Sekretarz, w sztuce rymotwórczej biegły, zlecenie swego pana wypełnił, król wiersz własnoręcznie, na obrazku czy obrazie Bogarodzicy, wypisał - i na tym koniec. Później dopiero stworzono legendę o talencie poetyckim króla. O tem, że Sobieski miał sobie cudzą pracę przywłaszczyć i w cudze piórka się stroić - mowy być nie może. Nie dopuszcza tego przypuszczenia najpierw prawy charakter króla, następnie okoliczność, że na przełomie wieku XVII-go i XVIII-go, w epoce ogólnego ściemniania umysłowego w kraju, nikt u nas w pisaniu wierszy chluby dla siebie nie szukał. Morsztynowie, Potocki Wacław i inni rymowali prawie w ukryciu, dla siebie i swych przyjaciół, o druku zgoła nie myśląc”.

${ }^{\text {I }}$ Zob. J. Janas, Ojczysta ,foza” $i$, maniera” wjezyku ,Rozmów listownych” Wojciecha Stanistawa Cbrościńskiego, „Barok” 1995, nr 2. 
czając, że formy te zostały po raz pierwszy użyte właśnie przez Chrościńskiego ${ }^{2}$.

Utwór Rozmowy listorene w zamiarze tłumacza, jak zauważa Mieczysław Klimowicz, „wypełnić miał rażącą lukę w literaturze polskiej - brak romansu listowego" ${ }^{33}$. Dokonanie Chrościńskiego stało się punktem odniesienia dla Pawła Zatorskiego, autora pierwszej polskiej sentymentalnej powieści w listach zatytułowanej Przydatek do wwag zupetnemu stanowiacych sięszczęściu shuzacych etc. Osobliwy, przez tego co i przedtem Podgórzanina Ich Mościow Kazwalerów ciekawości i pożytkowi poświęcony, to jest list listów rozlicznych do delikatnej o pozwolona przyjaźn, tomików dwa wydanej w dwóch tomach w Krakowie w roku 174654. Oprócz podobieństwa kompozycyjnego, polegającego między innymi na tym, że każdy kolejny wierszowany list poprzedzony jest objaśnieniem i streszczeniem wiadomości w nim zawartej, widoczne są wyraźne podobieństwa „pod względem treści i emocjonalnego stylu wypowiedzi" 55 .

W okresie niespokojnego czasu bezkrólewia po śmierci Jana III Sobieskiego pisze Chrościński dwa utwory: Lament strapionej ojczyzny po zerwaney konwokacyey sub tempus Interregni $i$ zwiazanych wojskach koronnych $i W$. Ks. Lit. nieszczęście swoje oplakujaccej ${ }^{6}$ oraz Projekt na mody francuskie w Polszcze57.

${ }^{2}$ Zob. ibidem. Badaczka dzieli się przy tym uwagą natury ogólnej, że „Rozmowy listowne zawierają cenny materiał do badań językowych” (s. 169). Na potwierdzenie tego zob. K. Siekierska, Język Wojciecha Stanistawa Chrościńskiego; J. Moszyńska, Cechy fonetyczne „Rozmów listownych” Stanistawa Cbrościńskiego, „Sprawozdania z Czynności i Posiedzeń Łódzkiego Towarzystwa Naukowego" 1968 , R. XXII, z. 3.

53 M. Klimowicz, Narodziny romansu listowego w literaturze polskiej, „Pamiętnik Literacki” 1958, z. 4, s. 415.

54 H. Dziechcińska, op.cit., s. 49.

55 Ibidem, s. 51. Dziechcińska wskazuje na obecność Chrościńskiego i jego znakomitego przekładu Heroides Owidiusza również w innych utworach Zatorskiego. Cytowane fragmenty pojawiają się na przykład w utworze Uwagi do zupetnego zabierajacych się w stan matżeński szczęścia stużące. W części pierwszej, będącej poradnikiem dla kawalera, przytacza Zatorski w konkluzji dwuwiersz z Rezmów listownych Chrościńskiego: „Należało mię wprzód prosić i pytać/ Nie przez fortele w skryte siatki chwytać”.

${ }^{56}$ Kopia egz. BUW sygn. 79 i sygn. 93 (tutaj znajduje się Apostrophe do Pana Chrościńskiego, autora tego Lamentu). Tekst, mylnie przypisując go W. Kochowskiemu, wydał A.E. Koźmian w Wyciagach piotrowickich, czyli niektórych wyjątkach z Ksiegozbioru Piotrowickiego, t. 1, Wrocław 1842, s. 65-81. Utwór wydał też, jako „nieznany wiersz Wojciecha Stanisława Chrościńskiego” (nie wiedząc o wydaniu A.E. Koźmiana), dr B. Erzepki w „Rocznikach Towarzystwa Przyjaciół Nauk Poznańskiego" 1895, t. 21. Tekst znajduje się też w antologii Poeci polskiego baroku, s. 433-445.

57 Tekst ogłosił A.E. Koźmian w Wyciagach piotrowickich, s. 82-86. Przedrukowany też został w zbiorze Poeci polskiego baroku, s. 445-448. 
Pierwszy, jak zaznacza jego wydawca Bolesław Erzepki, „wielu współczesnym znanym być musiał $\mathrm{i}$, jeżeli nie w druku, to w licznych odpisach $\mathrm{z}$ rąk do rąk rozchodził się po kraju wśród ogółu czytającej szlachty" ${ }^{58}$. Przemawiają za tym, według niego, dawne kopie Lamentu. Potwierdza to Paulina Buchwald-Pelcowa, która zauważa: „Zachowała się [...] taka liczba rękopiśmiennych kopii osiemnastowiecznych (czy z przełomu XVII/XVIII), że $\mathrm{z}$ dużą dozą prawdopodobieństwa możemy stwierdzić, iż był to utwór niewątpliwie popularny" 59 .

Poemat, który liczy 43 strofy, jest głosem stroskanej i skołatanej wieloma nieszczęściami ojczyzny, która w gorzkich i żałosnych słowach rozpamiętuje swój upadek. Po początkowej apostrofie do Matki-Ojczyzny odmalowany zostaje „smutny i przygnębiający obraz duchowej i moralnej nędzy, jaki przedstawiała Rzeczpospolita Polska z chwilą śmierci Jana Sobieskiego i powszechny zamęt, jaki zapanował w kraju po zejściu króla" ${ }^{60}$. Autor ustami Ojczyzny, którą przyrównuje do osierociałej wdowy, ukazuje żałosny stan położenia kraju:

O który królestw tak ciężkie machiny

I cały okrąg szerokiego świata

Bezpiecznie palcem swym dźwigasz jedyny

Wszechmocnej ręki w niezmierzone lata!

Sam kwitnąć dajesz państwom, sam ruiny

Czynisz i od nich sam oddalasz fata;

A wszelakiego szczęścia będąc słońcem,

Jesteś państw oraz początkiem i końcem.

Ty królewskimi dyrygujesz trony

I na wspaniałe wsadzasz majestaty.

Abdolonymów do złotej korony

Od ogrodniczej ordynujesz chaty.

Gdy zaś, co z każdej ach! Żałosna strony,

Państwa pokarzesz królewskiemi faty,

Sam radzisz z nich, sam w ojczyźnie panem,

Sameś w obozie Bogiem i hetmanem.

Osierociała wdowa i strapiona,

Do ciebie, sierót zacny opiekunie,

Matka od własnych synów opuszczona,

$5^{8}$ B. Erzepki, op.cit., s. 435.

59 P. Buchwald-Pelcowa, Satyra czasów saskich, Wrocław 1969, s. 149.

6o B. Erzepki, op.cit., s. 436. 
W ostatniej mojej uciekam fortunie.

Złośliwych zgraja na mnie sprzysiężona, W jednej z mym panem każe leżeć trunie. Przebóg! Zginiona, niechaj padnę trupem, I zajuszonej Prozerpiny łupem.

O wiele razy ćmiła się korona, Turecki księżyc kiedy był w ozdobie. O jak od hardych bisurman wzgardzona, Smutne requiem wynuciła sobie, W samej przepaści śmierci pogrążona, Ów tryumfalnej gdy zajaśniał w dobie. Jeszcze do tego, gdy tatarskie strzały $\mathrm{W}$ orła polskiego jako w cel zmierzały.

Orzeł, co pierwej pod same obłoki

Nad lotną strzałę wzbijał się wspaniały, Że go i Argus nie dojrzał stooki, I owszem świat mu dziwował się cały;

Teraz ach! W ciemne gdzieś zaleciał mroki

I Turczyn z niego śmieje się zuchwały:

Tatarskie wrony skrzydła mu wyrwały,

Piersi się tylko z ogonem zostały ${ }^{6 \mathrm{~T}}$.

Autor z uczuciem najgłębszego żalu wspomina zmarłego króla, zgon jego uznając za niepowetowaną stratę. W drugiej części poematu podejmuje kwestię przyszłej elekcji i kładąc przed oczy czytelnika galerię ubiegających się o polską koronę konkurentów, kandydatów do tronu, wykazuje ich słabości i jednoznacznie opowiada się za kandydaturą syna królewskiego Jakuba.

Wżdyć i z ojcowskich popiołów wyleci

Zrodzony feniks: polskie majestaty

Odrodzonemi nadziejmi oświeci,

Smutną żałobę zamieni w szkarłaty;

Powiędłe ojca odwagi ten wznieci,

Stary rozumem, chociaż młody laty;

Kiedy król ma być koloru różnego

Lech, Niemiec, Francuz, syn grzmotu do tego ${ }^{62}$.

Buchwald-Pelcowa podkreśla, że

6I Ibidem, s. 442-444.

${ }^{62}$ Ibidem, s. 458. 
Utrzymanie utworu w ramach kompozycyjnych lamentu, skargi Ojczyzny do Boga, wyrazistość poszczególnych obrazów (choć do ich logicznej wymowy możemy mieć zastrzeżenia), jedność stylistyczna utworu, w którym z powagą początkowych i końcowych apostrof nie kłóci się satyryczne, a przede wszystkim ironiczne przedstawienie zamieszania bezkrólewia, sprawia, że mimo pewnych niedociągnięć jest to jeden z lepszych utworów tego okresu ${ }^{63}$.

Również Claude Backvis, kwalifikując Lament jako utwór należący do gatunku quaerimoniae Reipublicae, zauważa, że „wyróżnia się on poziomem ambicji literackich" ${ }^{64}$, aczkolwiek razić może niekiedy przesadą i zawiłością stylu barokowej ekspresji ${ }^{65}$.

Podobny w wymowie do Lamentu jest utwór Do uciśnionej ojczyzny apostrophe, dołączony przez Chrościńskiego do Joba cierpiacego ${ }^{66}$. Autor skomponował jednak wiersz inaczej: nie Ojczyzna lamentuje nad swoją niedolą, ale spotykające ją nieszczęścia poeta wylicza w skierowanej do niej apostrofie. Jest to zatem wypowiedź skonstruowana $\mathrm{w}$ pierwszoosobowym autorskim „ja”. „Uciśniona ojczyzna” zostaje przyrównana do Joba, biblijnego symbolu nieszczęść i cierpień charakteryzujących ludzką kondycję. Istnieje jednak zasadnicza różnica: podczas gdy może się ona równać $\mathrm{z}$ Jobem $\mathrm{w}$ nieszczęściu, to $\mathrm{w}$ żaden sposób nie dorównuje mu $\mathrm{w}$ niewinności, dźwigając brzemię i ponosząc konsekwencje popełnionych win i błędów.

Buchwald-Pelcowa jest zdania, że w wierszu Do uciśnionejojczyzny apostrophe Chrościński nie tylko dorównuje Lamentowi, „ale nawet go przewyższa" ${ }^{67}$.

Projekt na mody francuskie w Polszcze jest satyrą, w której przenikają się wątki obyczajowe i polityczne. Treść jej stanowi krytyka szerzenia się wpływów francuskich za panowania Jana III Sobieskiego:

Bodaj te mody francuskie przepadły,

Co nam już kołnierz tak dobrze osiadły,

Że nie tylko swe zwyczaje ganiemy,

${ }^{63}$ P. Buchwald-Pelcowa, op.cit., s. 153.

${ }^{64}$ C. Backvis, Panorama poezji polskiej okresu baroku, red. A. Nowicka-Jeżowa, R. Krzywy, t. 2, Warszawa 2003, s. 233.

${ }_{65}$ Ibidem, s. 241.

${ }^{66}$ Pierwodruk: W.S. Chrościński, Job cierpiacy z dóbr i fortun reyzuty, Warszawa 1705. Utwór przedrukowany też w: Poecipolskiego baroku, s. 448-449 oraz w „I w odmianach czasu smak jest”. Antologia polskiej poezji epoki baroku, oprac. J. Sokołowska, Warszawa 1991, s. 608.

${ }_{67}$ P. Buchwald-Pelcowa, op.cit., s. 153. 
Ale żyć wszyscy po francusku chcemy.

Korzysta w swoim horyzoncie gwiazda,

Własnego żaden ptak nie brzydzi gniazda -

My tylko sami tak jesteśmy ślepi,

Że żyć z francuska wierzymy najlepiej ${ }^{68}$.

Autor występuje zdecydowanie przeciwko hołdowaniu cudzoziemskich mód i gani życie ponad stan. Ostrze satyry skierowane jest szczególnie w styl życia kobiety:

Tęskno jej w domu, nie wspomni o igle,

Myśl ją lub w pole wabi, lub na figle.

Bez konwersacje obejść się nie może,

Żadnej bez męża nie puści podroże.

A rzadko która z miłości to czyni,

Ażeby zdrowia mąż szanował przy niej;

Bardziej domowe zbrzydziwszy zabawy,

Żeby się mogła nasycić Warszawy.

$[\ldots]$

Już gdziekolwiek się mąż tylko wybierze,

Żona najpierwsze miejsce przed nim bierze,

Sejmu żadnego pewnie nie opóźni,

A gdy mąż z królem w zdaniu się poróżni,

Ona też mając w głowie swe prywaty

Insze z królową umawia traktaty ${ }^{69}$.

Doświadczony przeżyciami związanymi ze śmiercią Jana III Sobieskiego i smutnym okresem bezkrólewia, zaprzątnięty rodzinnymi troskami, odchodzi Chrościński od tematów świeckich i zwraca się ku tematyce religijnej. Pisze trzy poematy oparte na tematyce biblijnej. Najwcześniejszym z utworów, którego kopia rękopiśmienna pochodzi z roku 1698, jest Józef do Egiptu od Braci przedany, tam dla czystości inkarcerowany, potym dla wykładu snów od więzienia wolny $i$ do taski przypuszczony. Trzynasto pieśni ośmiorakiego rytmu ogtoszony Roku Pańskiego $1745^{\circ}$.

Następny, to napisany prawdopodobnie w roku 1701 lub 1702, Job cierpiacy z dóbr i fortun wyzuty, na dzieciach $i$ zdrowiu dotkniony, a po tym przez taskę i mitosierdzie Boskie nad wszel-

${ }^{68}$ W.S. Chrościński, Projekt na mody francuskie w Polszcze, w: Poeci polskiego baroku, s. 445.

69 Ibidem, s. 446-447.

70 Egz. Ossolineum sygn. XVIII-1667. Egz. BUW sygn. 4.19.7.70. Egz. BN sygn. XVIII.1.4415. Rękopis Ossolineum nr 864/I. Kopie: Ossolineum 940/I, $1837 / \mathrm{I}$. 
kie mniemanie przyjaciót swoich usprawiedliwiony $i$ wszystkim we dwoy nasób nadany z tacińskiego na polskie wedtug Kommentu S. Grzegorza Wielkiego Kościelnego Doktora wierszem przełożony w Roku Pańskim 1705 przez Wojciecha Stanistawa Chrościńskiego J. K. Mci Sekretarza do druku podany w Warszawie w Drukarni Ojców Scholarum Piarum $^{71}$. Do dzieła dołączył autor Threny Hieremiaszowe albo Lamentacye na wielki tydzień postny ${ }^{72}$.

Trzeci utwór nosi tytuł Aman od Asswerusa Króla Perskiego i Medyjskiego nad wszystkie inne Ksiażęta wywyzszony dla pychy $i$ żości swojej gdy ród caby żydowski na zemstę wygubić usituje. Z pierwszej godności wyzuty $i$ na szubienicy obwieszony. Dziewiacia pieśni ośmiorakiego rytmu z Ksiag Estery Królowej opisany w Roku Pańskim $1745^{73}$.

Tylko Job cierpiacy... ukazał się drukiem za życia Chrościńskiego w roku 1705, pozostałe dwa utwory wyszły już po śmierci poety w roku 1745 , oba bez oznaczenia miejsca wydania ${ }^{74}$.

W roku 1706 wychodzi tłumaczenie łacińskich wierszy Florianusa a Santo Hieronymo (właściwie Floriana Kreydy) na cześć Matki Boskiej zatytułowane Laurus poetica inter Sacra Anathemata ad aram Beatae Mariae Virginis in arenis Cracoviae pro voto felicis Philosophici Cursus Chetmensis Nomine tum suo, tum Caete-

${ }^{71}$ Egz. Biblioteki Kórnickiej PAN sygn. 128940, 19022. Egz. BUW sygn. 4.28.6.15. Egz. BN sygn. XVIII.2.1171; XVIII.2.2455; XVIII.2.2569.

${ }^{72}$ Mieszczą się one na stronach 175-204.

73 Egz. BUW sygn. 4.19.8.69.

${ }^{74}$ K. Estreicher wskazuje jako miejsce wydania Amana Kraków - zob. K. Estreicher, Bibliografia polska, część 3, tom III (ogólnego zbioru tom 14), Kraków 1896, s. 215 i 216. Jak zauważa K. Siekierska (Język Wojciecha Stanistawa Chrościńskiego, s. 8): „Niektórzy badacze literatury utrzymują, że istniało wcześniejsze wydanie Amana z roku 1705 lub nawet 1703, nie wymienia jednak takiego wydania ani Estreicher, ani Korbut”. Tu wskazuje autorka Encyklopedię powszechna Orgelbranda, t. 5, s. 522 oraz W. Jędrychowskiego, Próbę rekonstrukcji biografii, s. 218-219. Z kolei M. Kowalska (Do biografii Wojciecha Stanistawa Chrościńskiego, „Ruch Literacki” 1930, nr 10, s. 327-328), wprowadzając poprawki do artykułu W. Jędrychowskiego, wydanie Joba cierpiacego przesuwa z roku 1705 na rok 1703, „o ile ta trójka w 1703 nie jest omyłką drukarską z piątką, gdyż popularne wydanie Joba pochodzi z r. 1705, chociaż w wydaniu pierwszem Słownika Lindego z r. 1807 podany jest rok druku Joba Warszawa 1704, o czem również Bentkowski: Hist.l.p. T.I, str. 375, Warsz. 1814. Przypuszczalnie był więc Job napisany przed rokiem 1703, to jest w 1702 r. Do wniosku tego doszłam w następujący sposób: W wydaniu Joba z r. 1705 Warszawa pisze Chrościński Do czytelnika, że Z okazyjej nieszczęścia i przypadku mego przed lat pięcia, umacniając się w cierpliwości, przetożytem umyślnie tę historia Joba Sprawiedliwego... i.t.d. Jakiż to mógł być wypadek? Chyba tylko śmierć pierwszej żony, która, jak z tego wypadałoby, umarła raczej w roku 1697, a nie w 1703, jak przypuszcza p. Jędrychowski. Było to więc też po śmierci uwielbianego przez poetę króla Jana Sobieskiego, dlatego to zabrał się Chrościński do powyższego tematu. Przecież nawet w końcowej Apostrofie porównuje zkancerowaną Ojczyznę po śmierci króla do Joba”. 
roru Condiscipuloru per P. Florianum a S. Hieronymo Scholarum Piarum Appena Anno Domini 1701 Patrio autem Carmine Anno Domini 1705, per M.D. Adalbertum Chroscinski S RM Secretarium explicata Varsaviae Typis Collegia Scholarum Piarum Reimpressa Anno Domini 1706 (Laur poetyczny czyli pieśni na pochwate Najśzwiętszej Maryi Panny) 75.

Śmierć pierwszej żony związana jest z powstaniem cyklu lirycznych wierszy pod tytułem Threny żałobne po śmierci niegdy godnej pamięci napisane Jej Mości Paniey Agnieszce Chrościńskiej Sekretarzowey I KM. Od osierociałego iey matzonka Jegomości Pana Wojciecha Stanistawa Chrościńskiego I KM Sekretarza w Roku Pańskim 1709 w Drukarni Jasnej Góry Częstochowskiej ${ }^{6}$. Autor opisał chorobę, leczenie w Krakowie i pogrzeb żony ${ }^{77}$.

$\mathrm{W}$ roku $1710^{7^{8}}$ ukazuje się tom wierszy zatytułowany Krótki zbiór duchownych zabaw ojczystym wierszem przezJego Mości Pana

75 Egz. Biblioteki Kórnickiej PAN sygn. 115393. Egz. Ossolineum sygn. XVII-230. Egz. BUW sygn. 142175. Utwór Na narodzenie Najświętszej Panny Maryjej pieśn druga $\mathrm{w}$ antologii polskiej poezji barokowej Helikon sarmacki, s. $153-156$.

${ }^{76}$ Egz. BUW sygn. 4.19.7.62a.

77 T. Skubalanka (Stownik literatury staropolskiej Średniowiecze - Renesans - Barok, red. T. Michałowska. B. Otwinowska, E. Sarnowska-Temeriusz, Wrocław 1998, s. 915), zwracając uwagę na obecne w utworze obniżenie wartości estetycznych poezji, pisze: „Kiedy [...] W.S. Chrościński w Trenach załobnych (1709) poświęconych zmarłej żonie, przyrównując ją do pelikana, używa apostrofy kochana samico, odnosimy wrażenie, że zachwianie normy stylistycznej, jakie obserwowaliśmy już w w. XVII, dochodzi tutaj do zenitu".

${ }^{7}$ Drugie wydanie ukazuje się już w roku następnym. Zob. K. Estreicher, op.cit., s. 217. Do drugiego wydania, bez wskazania na karcie tytułowej, dołączone zostały na końcu Quinque Psalmi in detentione Gluchoviensi compositi M.S. Wiśniowieckiego, brata J. Korybuta, a postać ich autora zaszyfrowana została pod niezbyt czytelnym anagramem „Machisii Secundi Civis Lovei”. Owe pięć Psalmów stało się przedmiotem analiz w następujących artykułach: B. Strzyż-Judkowiak, Z kart literatury zapomnianej, „Ruch Literacki” 1984, nr 5-6, s. 395-410; M. Prejs, „Barok uspokojony” - „Psalmy” Michała Serwacego Wiśniowieckiego, „Barok” 2000, z. 2, s. 95-108. Judkowiak, wskazując na relację cyklu Wiśniowieckiego z wzorcem biblijnym, konstatuje, że utwory te wiążą się z jednej strony „,z silnym, choć wąskim prądem tradycji literackiej baroku - nurtem poetyki klasycystycznej (Sarbiewski, Opalińscy)”, z drugiej zaś „są one także bliskie już konsekwencjom nowej, francuskiej koncepcji sztuki, opartej na przesłankach racjonalistycznych, w której rozum i funkcje poznawcze stały się kryterium piękna” (s. 408). Prowadzi to badaczkę do sformułowania następującej tezy: „Ukazując przejściowy niejako charakter twórczości poetyckiej Michała Serwacego Wiśniowieckiego, przesuwamy ostrożnie z lat trzydziestych i czterdziestych osiemnastego stulecia «zalążki programu odrodzenia poezji polskiej» - manifestowane raczej w praktyce, w poetyce immanentnej - na okolice roku 1710” (s. 410). Prejs, oceniając powyższą tezę jako „atrakcyjną i kuszącą”, nie znajduje dla niej jednak potwierdzenia w lekturze cyklu Wiśniowieckiego. „Psalmy bowiem w najmniejszym stopniu nie 
Wojciecha Stanistawa Chrościńskiego I KM Sekretarza napisany a dla pobożnej w teraźniejszych utrapieniach folgi do druku podany Roku Pańskiego 1710 w Drukarni Jasnej Góry Czestochowskiej ${ }^{9}$ pisany, jak zaznacza autor, „dla pobożnej w teraźniejszych utrapieniach folgi”, z aprobacją Petrusa Praclewicza, doktora teologii, kanonika katedry krakowskiej, dedykowany „swemu wielce Miłościwemu Panu” Januszowi Korybutowi Wiśniowieckiemu, wojewodzie krakowskiemu, marszałkowi trybunału koronnego $^{8 \circ}$. Obejmuje on: Pacierz z różnych miejsc Pisma śreiętego zebrany a podczas inkursjej szwedzkiej do Polski w roku 1702 wierszem opisany $^{8 \mathrm{x}}$, siedem Psalmów spowiednych, Pięć psalmów na imię Jezus, Drugie pięć psalmów na imię Maryja, Pieśni na uroczystości przedniejsze Najśzwiętszej Boga-Rodzice Panny Maryjej ${ }^{8_{2}}$, Żywot świętego Aleksego wyznawcy i Żywot i męczeństwo świętego Eustachiusza hetmana rzymskiego $i$ żony, $i$ dreu synów jego.

Ostatnim utworem Chrościńskiego jest napisany po łacinie panegiryk sławiący genealogię rodu Sobieskich: Clipeus Serenis-

wybiegają w przyszłość na spotkanie literatury oświeceniowej, całkowicie natomiast zorientowane są na bliską przecież, siedemnastowieczną przeszłość, zaś w szczególności na różnorodność i bogactwo ówczesnej poezji religijnej w całej jej złożoności i ekspansywności. Wiśniowiecki całkiem świadomie tradycję tę powtarza, cyzelując i delektując się jej smakiem, po swojemu ją przetwarzając i zmieniając, ale tylko w takim zakresie, aby móc zamanifestować swoją oryginalność twórczą, nigdy zaś nie doprowadzając do zatarcia czytelności barokowego paradygmatu" (s. 96). Badacz orzeka zatem w konsekwencji jednoznacznie: „Psalmy Michała Serwacego Wiśniowieckiego to jakby kompendium barokowej liryki religijnej w ogóle, tak zostały obmyślane i tak napisane. Próby oderwania tego tekstu od tej właśnie tradycji, którą się żywi, byłyby największym błędem, jakiego można by się w stosunku do jego poezji dopuścić” (s. 102).

79 Egz. Ossolineum sygn. XVIII-287. Egz. BN sygn. W.1.1095; XVIII. 2.834. Wydanie $\mathrm{z}$ roku 1711 egz. BUW sygn. 4.19.7.62b oraz 4.19.7.69.

8。 Dedykację rozpoczyna autor następująco: „W tak ciężkim razie strapionej Ojczyzny, / Przez żelaznego wieku panowanie,/ Gdy nic nie słychać, tylko mordy, blizny, / Zniszczenie włości; granic najeżdżanie,/ Gdy kraj bez ludzi, grunt bez robocizny, / Czego przyczyną wnętrzne zamieszanie,/ Gdy w całej Polszcze potrzebna pokuta,/ Idzie duchowny wiersz do KORYBUTA".

${ }^{8 I}$ Pacierz chrześcijański stanowił popularną w baroku formę medytacji nad kolejnymi wersami Ojcze nasz (np. K. Bonisławska).

${ }_{82}$ Jeden z wierszy zatytułowany Wiersz ofiarny Najświętszej Pannie Maryjej na Piasku w Krakowie również jako oryginalny utwór Chrościńskiego przedrukowany w zbiorze Poeci polskiego baroku, s. 450-451 oraz w antologii: Z Libera, Poezja polska XVIII wieku, Warszawa 1976, s. 68-70. Inny pod tytułem O Niepokalanym poczęciu Najśziętszej Panny Maryi przedrukowany w: Polska poezja maryjna, antologia w układzie T. Jodełki, przedmowa J. Zawieyski, Niepokalanów 1949, s. 93-95. Jak zauważa J. Starnawski (Chrościński, Cbruściński Wojciech Stanistaw, w: Encyklopedia Katolicka KUL, red. R. Łukaszyk, L. Bieńkowski, F. Gryglewicz, t. 3, Lublin 1979, s. 290), „dzięki temu cyklowi Chrościński stał się jednym z poprzedników K. Bonisławskiej”. 


\section{simi Ioannis III, wydany w roku $1717 \mathrm{w}$ Brzegu $^{83}$. Tadeusz Korzon tak pisze o tym utworze:}

najobfitszą w imiona i najrozciąglejszą co do czasu genealogię zaprodukował Stanislaus Adalbertus Chruściński, secretarius regius, w dedykowanej królewicowi Jakubowi Historyi chronologicznej Najjaśn. domu Sobieskich p.t. Clipeus serenissimi Joannis III... Anno 1717. Brigae Typis Godofredi Trampiii. Rozpoczyna on od Lecha I, założyciela księstwa polskiego około 470 r. po Chr; następnie przez Wissimira, 12-tu wojewodów i Przemysława czy Leszka I do Leszka I i t. d., kończy zaś na wnukach Jana III. [...] Widoczną jest w całej tej pracy mała znajomość historyi obok wielkiej chęci przypodobania się królewicowi Jakubowi przez wytworzenie jak najświetniejszych kolligacyj dla rodziców jego ${ }^{84}$.

${ }^{8} 3$ Egz. Biblioteki Kórnickiej PAN 32603. Egz. BUW sygn. 4.2.3.3. oraz 13.18.1.53/1. Egz. BN sygn. W.3827; XVIII.3.1302; XVIII.3.1641; XVIII.3.1831; XVIII.3.2626; XVIII.3.5672. K. Siekierska (Jezyk Wojciecha Stanistawa Chrościńskiego, s. 9) zauważa w tym kontekście: „Istnieją jeszcze dwa wiersze, znane $\mathrm{z}$ rękopisów lub późnych druków, o których autorstwo posądza się Chrościńskiego. Jest to po pierwsze cytowany przez W. Roszkowską Otawa królewiczów Sobieskich, Wrocław 1968, s. 138, a znajdujący się w Ossolineum 249/III utwór przypisywany także królewnie Klementynie Sobieskiej, zaczynający się od słów: Cesarz mi się do domu wrocić roskazuie... oraz drukowana $\mathrm{w}$ «Monitorze» z r. 1776 (t. II, s. 467-469) Parodia Ody Horacyuszowey. Oba te utwory mogą być napisane przez Chrościńskiego, nie ma w nich jednak jakichś cech charakterystycznych, które by pozwoliły w sposób zdecydowany opowiedzieć się za tym poetą. Jeszcze jeden utwór notowany jest w bibliografiach jako dzieło Chrościńskiego. Jest to: Ciekawość większa nad kolędę warszaweską w Roku 1794. Utwór ten jest jednak tylko przedrukiem Apostrofe do uciśnionej ojczyzny (część Joba) wydrukowanym wraz z (wyjętym z Ksieggi Historycznej Zakonu Prowincji Wielkopolskiej) opisem komety z r. 1692. Przypisuje się Chrościńskiemu także autorstwo dołączonych do autografu Józefa i przepisanych tą samą ręką Poezji Postu Świętego. Zbyt wiele cech różni je jednak od innych utworów Chrościńskiego, aby uznać te wiersze za jego dzieła”. Zob. Chrościński Wojciech Stanisław (ok. 1665-po 1722), Utwory o autorstwie niepewnym, w: Bibliografia literatury polskiej Nowy Kerbut, s. 84; Chrościński Wojciech Stanistaw (ok. 1660-ok. 1722) Utwory o autorstwie niepewnym, w: Dawni pisarze polscy, s. 170-171. W. Ogrodziński (Polskie przekłady Horacego, Kraków 1935, s. s. 67) wspomina o thumaczeniu przez Chrościńskiego utworu Horacego następująco: „parafrazy i trawestacje ciągną się poza wiek XVII. Na schyłku jego przetworzy epodę 7 i do ówczesnych polskich stosunków przykroi Wojciech Chrościński p.t. Parodia Ody Horacjuszowej: Quo quo scelesti ruitis, epod VII”. O kwestiach wiążących się z autorstwem Sonetu na cała Mękę Pańska zob. T. Mikulski, Dzieje jednego sonetu. Chrościński, Lubomirski czy Radziewicz?, „Ruch Literacki” 1929, nr 4 (przedruk: T. Mikulski, Rzeczy staropolskie, s. 353-356) oraz Literatura polska w autografach Biblioteki Zakładu Narodowego im. Ossolinskich we Wroctawiu, katalog oprac. T. Mikulski, Wrocław 1947 [tu: Czasy saskie. Wojciech Stanistaw Chrościński (ok. 1665-po 172). Sonet na cała Mękę Pańska, s. 19-20]. Tekst jako utwór S.H. Lubomirskiego opublikowany w antologii Sonet polski, oprac. W. Folkierski, Kraków 1925, s. 41.

${ }_{4}$ T. Korzon, Dola i niedola Jana Sobieskiego 1629-1674, Kraków 1898, t. 1, s. 547. 
„Opinie znawców literatury o twórczości Chrościńskiego nie są zgodne" ${ }^{85}$, zauważa Siekierska i jest w tym stwierdzeniu badaczki języka poety (opatruje je odpowiednimi przykładami) zasadnicza słuszność. Przyjrzyjmy się zatem sądom wyrażanym o literackim dziele Chrościńskiego. Jak pisze Siekierska: „Do końca XVIII w. Chrościński był znanym i cenionym poetą" ${ }^{86}$.

W tomie VIII pisma „Nouvelles litteraires contenant ce qui se passe de plus considérable dans la République des lettres", wydawanego w Hadze, z roku 1718, znajduje się recenzja utworu Chrościńskiego Clypeus Serenissimi Joannie III.... „Wyjaśniwszy na początku koncepcję dzieła (historia rodu bohatera i jego żony) i opowiedziawszy fabułę, recenzent charakteryzuje styl autora, wskazuje związki z antykiem, cytuje łacińską konkluzję mówiącą o trwałej sławie Sobieskiego" ${ }^{87}$.

Chrościńskiego wymienia także, jako autora Krótkiego zbioru duchownych zabaw to jest pacierza, psalmów pokutnych i pieśni różnych, wydanego w Częstochowie w roku 1711, w swoim opracowaniu Polnische Liedergeschichte torunianin Ephraim Oloff. Rzecz została wydana po śmierci autora (zm. 1735), w roku 1744, przez Sylviusa Wilhelma Ringeltaubego ${ }^{88}$.

W roku 1751 Józef Aleksander Jabłonowski ogłosił tom Ostafi po polsku, Eustachius po tacinie, Placyd po świecku..., dołączając naukę o wierszach i wierszopisach polskich wszystkich [...]. W poczet poetów polskich, zaczynający się od Paprockiego, zaliczył również Chrościńskiego ${ }^{89}$.

Nauka o wierszach $i$ wierszopisach polskich poprzedza prozaiczną biografię, następnie poemat w oktawach o świętym Eustachym (Placydzie). Stąd tytuł książki. Wyjaśnia wydawca, że utwór jest Chrościńskiego i ogłoszony był w 1711 roku, ale też on, Jabłonow-

${ }_{5}$ K. Siekierska, Język Wojciecha Stanistawa Chrościńskiego, s. 10.

${ }^{86}$ Ibidem.

87 J. Starnawski, Dzieje wiedzy o literaturze polskiej (do końca wieku XVIII), Wrocław 1984, s. 135.

${ }^{88}$ E. Oloff, Polnische Liedergeschichte von polnischen Kirchen - Gesängen und dererselben Dichtern und Übersetzern nebst einigen Anmerkungen aus der polnischen Kirchen - und Gelehrten - Geschichte, Danzig 1744, s. 39 (Fotomechanischer Neudruck der Orginalausgabe 1744 nach dem Exemplar der Sächsischen Landesbibliothek Dresdnen, Leipzig 1976). J. Starnawski wspomina o istnieniu wydania 2 zatytułowanego Beiträge der polnischen weltlichen Kirchen und Gelebrtengeschichte, Danzig 1764. „Różnic w tekście obu wydań nie ma; w wyd. 2 - dodana obszerna część o bibliach, już nie Oloffa, lecz Ringeltaubego" (J. Starnawski, Dzieje wiedzy o literaturze polskiej, s. 135). Zob. także: S. Salmanowicz, Efraim Oloff (1685-1735) badacz literatury polskiej, erudyta toruński czasów saskich, „Ruch Literacki” 1972, z. 5, s. 299-305.

${ }^{89}$ J. Starnawski, Dzieje wiedzy o literaturze polskiej, s. 195. 
ski, przyozdobił go w drugiej redakcji i opatrzył strofami początkową i końcową ${ }^{90}$.

Z kolei w dziele Bibliotheca Jablonoviana, wydanym w roku 1755 katalogu zasobnej własnej biblioteki, w dziale Oratores et poëtae recentiores tomu 1, pisze Jabłonowski o tłumaczeniu Farsalii Lukana przez Wojciecha Stanisława Chrościńskiego ${ }^{9 \mathrm{I}}$.

Józef Jędrzej Załuski określa Chrościńskiego „celeberrimus Coriphaeus”, „nie omieszkając, jak pisze Konstanty Marian Górski, przekazać pamięci późnych wieków epigramatu, który niegdyś na jego nazwisko ułożył" ${ }^{92}$ :

Nie zazdroszczę Parnaskich Laurów Apollonie

Cne u nas rosną Laury nawet i w Chróścinie ${ }^{93}$.

W dziele-podręczniku Juvenela de Carlancas Essais sur l'bistoire des belles lettres, des Sciences et des Arts, wydanym we Francji trzykrotnie w 1740, 1749 i 1759 roku, a zaadaptowanym na język polski jako Historyja nauk wyzwolonych przez Imć.P. Juvenel de Carlencas francuskim językiem pisana, na polski przetożona ad usum Korpusu Kadetow JK Mci i wydanym w Warszawie w roku 1766 „nakładem Towarzystwa Literatów w Polszcze ustanowionego", przez tłumacza, jak to wskazał Adam Benedykt Jocher w pierwszym tomie Obrazu bibliograficzno-bistorycznego literatury i nauk w Polsce... (1840), którym był jezuita Górski, wymienione zostały trzy utwory Chrościńskiego: tłumaczenie Farsalii, Listy dam greckich Owidyjusza i Job ${ }^{94}$.

W czasopiśmie „Polak Patryjota”, w syntetycznym artykule zatytułowanym Literatura. Uwagi nad stanem nauk u nas (1785, t. 2, nr 12 i 14), jako wielcy poeci wymienieni zostali: Kochanowscy, Simonides, Kochowski, Twardowski, Potocki i Chrościński ${ }^{95}$.

90 Ibidem, s. 196.

${ }^{\text {II }}$ Ibidem, s. 177-178.

$9^{2}$ K.M. Górski, op.cit., s. 143.

93 J.J. Załuski, Bibliotheca poetarum polonorum qui patrio sermone scripserunt, Varsaviae 1754, s. 34.

94 J. Starnawski, Dzieje wiedzy o literaturze polskiej, s. 202, 204. Zob. na temat podręcznika: M. Miterzanka-Dobrowolska, O pierweszym podręczniku do nauki bistorii i teorii literatury wjęzyku polskim. Szkic z dziejów kultury i oświaty polskiego Oświecenia, „Zeszyty Naukowe WSP w Katowicach” 1956, s. 78-127. Autorka przypisuje pracę tłumaczenia podręcznika W. Górskiemu. Informacje o hipotezach dotyczących tłumacza podaje J. Starnawski w przyp. 2 do rozdz. V (Dzieje wiedzy o literaturze polskiej, s. 202-203).

95 J. Starnawski, Dzieje wiedzy o literaturze polskiej, s. 313. 
Z kolei Filip Nereusz Golański, autor podręcznika poetyki i retoryki $O$ wymowie $i$ poezyji $(1786,1788,1808)$, charakteryzując wiek XVII, eksponuje trzech sławnych poetów: Twardowskiego, Chrościńskiego i Kochowskiego ${ }^{96}$.

Wśród najznakomitszych poetów epoki umieszcza Chrościńskiego, w pracy O rymotworstwie irymotworcach, Ignacy Krasicki, który, pisząc o Lukanie, wspomina edycję polską Benedykta z Koźmina z 1533 roku i przekłady Farsalii Bardzińskiego oraz Chrościńskiego ${ }^{97}$. W Opisaniu podróży z Warszawy do Bitgoraja zamieszczonym w liście do J.O. Książęca IMCi Stanisława Poniatowskiego (1783) pisze Krasicki, przejeżdżając przez Ujazdów, o Janie III, który „w cieniu rozłożonych jaworów” przechadza się „, z pisarzem Anti-Lukrecjuszem”, rozmawia z „godnym posiedzenia swojego Lubomirskim" i wraz z Jabłonowskim słucha „poważnych rytmów Chrościńskiego" ${ }^{8}$.

Franciszek Ksawery Dmochowski w Sztuce rymotwórczej (1788) po pochwale Piotra Kochanowskiego jako tłumacza pisze:

Wiekiem później Kochowski słodkim lutni pieniem,

Twardowski żwawym tonem, Chrościński obfitym,

Bardziński, Otwinowski rytmem wyśmienitym

Słowiacząc dawnych pięknej szukający chwały,

I thumacz „Argenidy”, Potocki wspaniały,

Bystrymi kroki biegli śladem tego męża.

Wielu się doń przybliża, żaden nie zwycięża ${ }^{99}$.

„Chrościński musiał się też cieszyć dużym uznaniem Lindego, liczba cytatów z utworów tego poety jest w Stowniku języka polskiego wyjątkowo duża" ${ }^{\text {тоo }}$.

W opinii Hieronima Juszyńskiego największe uznanie zyskują Rozmowy listowne:

Piękne to thumaczenie, pierwszym pomiędzy dziełami Chrościńskiego liczone być powinno. $\mathrm{Z}$ dwóch wierszy autora robił cztery, ale tak szczęśliwie, że nieco rozszerzywszy, myśl Owidiusza zrozu-

${ }_{96}$ Ibidem, s. 323.

97 I. Krasicki, Dzieła, Warszawa 1829, t. 3, s. 166.

${ }_{98}^{8}$ J. Starnawski, Dzieje wiedzy o literaturze polskiej, s. 299.

99 F.K. Dmochowski, Sztuka rymotwórcza, oprac. S. Pietraszko, Wrocław 1956, s. 26-27.

тоо K. Siekierska, Język Wojciecha Stanistawa Chrościńskiego, s. 10. Stownik jezyka polskiego (t. 1-6) wydany został w Warszawie w latach 1807-1814, dokąd Linde przeniósł się w 1803 z Wiednia. Wydanie 2 uzupełnione przez A. Bielowskiego na podstawie rękopisów Lindego ukazało się we Lwowie w latach 1845-1860 . 
mialszą uczynił. Że jednak żył w wieku, gdzie czystość mowy już skażoną była, używał tedy często wyrazów obcych, przenośni mniej stosownych. Mimo tych jednak małych błędów w wielu miejscach piękności oryginału dobrze oddał i praca jego uważaną być może z pomiędzy tłumaczeń z łacińskiego za niepoślednią. Moim zdaniem w tym największa zaleta, że w stylu tak prostym jak jest to thumaczenie, tyle się mocy i wdzięków znajduje ${ }^{\mathrm{ToI}}$.

W Jobie cierpiacym... z kolei dostrzega Juszyński „wiersz gładki, styl lepszy jak w innych dziełach, myśli piękne. I to dzieło jest znaczną częścią tego lauru, który się słusznie zawsze Chrościńskiemu należał" "оо2. Te same słowa odnosi do Amana... Nie wzbudza już jednak uznania autora Dykcjonarza tłumaczenie Pharsalii, które podsumowuje: „Historia ta nierównie lepsza by była $\mathrm{w}$ prozie, i lubo $\mathrm{w}$ wielu miejscach wiersz dosyć piękny i gładki, Chrościński jednak w niej pokazał więcej łatwości w tworzeniu wiersza, niż mocy i ducha prawdziwej poezji" ${ }^{\text {I03. }}$ Sądy te powtarza prawie dosłownie Ignacy Chodynicki ${ }^{\mathrm{I0}}$.

Kazimierz Brodziński, charakteryzując Chrościńskiego, zauważa, że „nie jest bez talentu, lubo dość ma gładką polszczyznę, nie może się jednak liczyć do smakownych pisarzów”, a za najlepsze z jego dzieł uznaje Heroidy Owidiusza "wtenczas, gdy nie są z oryginałem porównywane”, ponieważ „tłumacząc piękne to dzieło wierszem ośmiozgłoskowym, nadać mu musiał zbytnią rozległość i zepsuć moc i dowcip wrażeń Owidyjusza” " ${ }^{\circ 05}$. Nie zyskuje też uznania Brodzińskiego tłumaczenie dzieła Lukana: „Lukan sam z siebie rozwlekły i nadęty, nierównie więcej w tłumaczeniu tym rozszerzony został. Co do kontynuacji Chrościńskiego, jest to tylko opis historyczny tęschnym wierszem bez żadnej poetycznej wizji” ${ }^{\text {Io6. }}$.

Bardzo krytyczną ocenę wiersza Do uciśnionej ojczyznyy, dołączonego do Joba cierpiacego, daje Euzebiusz Słowacki:

Elegia Wojciecha Chrościńskiego o nędzach ojczyzny, lubo zawiera w sobie myśli i zdania prawdziwe; nie jest jednak ani piękną poezją, ani dobrą elegią. [...] Porównanie nieszczęść ojczyzny do cierpień Joba, a stąd wynikające myśli, które autor przez całą elegię przecią-

\footnotetext{
тог H. Juszyński, Dykcjonarz poetów polskich, t. 1, Kraków 1820, s. 48-49.

то2 Ibidem, s. 49.

то3 Ibidem.

${ }^{104}$ I. Chodynicki, Dykcjonarz uczonych Polaków, Lwów 1833, s. 75-76.

ro5 K. Brodziński, Pisma, t. 4, Warszawa 1872, s. 250-251.

${ }^{\text {ro6 }}$ Ibidem, s. 251.
} 
ga, podają mu wiele opisów nieprzyjemnych, wyrazów nieszlachetnych i wstręt wzniecających ${ }^{\text {107 }}$.

Felicjan Faliński, śledząc żywotność i wpływ Trenów Jana Kochanowskiego jako cyklicznego wzorca trenologicznego, zauważa, że wśród „całego szeregu naśladowców wielkiego poety” zaledwie kilku „opłakiwało straty osobiste”, podczas gdy większość stawała się „odgłosem dolegliwości publicznych”. Zwraca przy tym uwagę, że do tych nielicznych wyjątków należą „ci, którzy [...] są jednocześnie znakomitościami górującymi rozmaite epoki; nie kto inny to bowiem jak: Grochowski, Morolski, Twardowski, Kochowski i Chrościński” ${ }^{\text {о⒏ }}$

Wśród najzdolniejszych tłumaczy literatury starożytnej swego czasu, obok Jana Allana Bardzińskiego, umieszcza Chro-

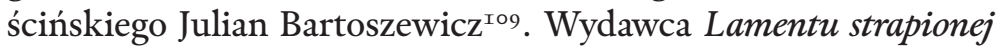
ojczyzny Bolesław Erzepki dokonuje z kolei następującej oceny utworu:

Nie myślimy tutaj wcale przeceniać ani wartości ani znaczenia $L a-$ mentu, nużącego częstokroć zawiłą rozwlekłością i przeładowanego aż do zbytku reminiscencjami klasycznymi, choć odznaczającego się w kilku miejscach niezwykłą siłą wysłowienia i poetyckiego zacięcia; wszelako przyznać trzeba, że literacki zabytek ten w ogóle dobrze i pięknie świadczy zarówno o pisarskim talencie autora swego jak o zacnym i szlachetnym jego sercu ${ }^{\text {IIo }}$.

Erzepki dostrzega w wierszu ,te same [...] wady i zalety, co tak dobitnie cechują wszystkie znane płody tego w swoim rodzaju bądź co bądź oryginalnego wierszopisa" ${ }^{I I I}$.

Piotr Chmielowski, dokonując przeglądu dziejów piśmiennictwa polskiego drugiej połowy XVII wieku, stwierdza, że w poezji tego czasu nie brak talentów, jednakże pozostają one w cieniu i nie objawiają w pełni swych walorów poetyckich, pos. 162 .

то7 E. Słowacki, Dzieła z pozostałych rękopisów ogłoszone, t. 3, Wilno 1826,

ro8 F. Faleński, Treny Jana Kochanowskiego, „Biblioteka Warszawska” 1866, t. 1, s. 71 .

ro9 J. Bartoszewicz, Dzieła, t. 2, Kraków 1877, s. 9 (rozdz. Epoka języka makaronicznego i panegiryków).

I о Lament strapionejojczyzny po zerwanejkonwokacyjej sub tempu interregna $i$ związanych wojskach koronnych $i$ W. Ks. Lit. nieszczęście swoje opłakujacej, nieznany wiersz Wojciecha Stanisława Chrościńskiego wyd. B. Erzepki, „Roczniki Towarzystwa Przyjaciół Nauk Poznańskiego” 1895, t. 21, s. 438.

III Ibidem, s. 439. 
nieważ „poczytnością cieszą się tacy napuszeni rymotwórcy, jak Stanisław Chrościński lub Jan Alan Bardziński” ${ }^{\mathrm{II} 2}$.

Sformułowanie o „napuszoności” pojawi się również w ocenie tłumaczenia Pharsalii Lukana przez Stanisława Spławińskiego. Komentując dwie oktawy skierowane do „czytelnika”, którymi została poprzedzona Traba wiekopomnej stawy Jana III:

Entuzjazmem kogo swym Kameny

Nie napuszyły, niech nie wchodzi w szranki

Z Muzami...

i w których wykłada poeta pogląd na to, kogo należy uznać za prawdziwego poetę, Spławiński konstatuje:

Jest więc Chrościński w swych zapatrywaniach zgodny z modą literacką XVII w., która nakazywała poecie być napuszonym, i, zgodnie z rzeszą dyletantów literackich, którzy tak gromadnie występują w tym wieku, pisze bombastyczny poemat, choć przyznaje, że „daleko ja się tułam od Parnasu” ${ }^{113}$.

Przechodząc zaś do charakterystyki samego tłumaczenia tak rzecz objaśnia:

Także na epopeję Lukana spogląda Chrościński przez okulary, nałożone mu przez modę wieku. [...] Rozpatrując epopeję Lukana na tle współczesnych mu czasów, pozostających pod przeważnym wpływem szkół retorów, uznaliśmy za jedną z jej cech ujemnych owo żonglerstwo słowami i myślami, chęć zaskoczenia i zadziwienia czytelnika, co w końcowym efekcie wiodło niejednokrotnie do zupełnej zatraty miary, do rozwlekłości, wynikającej z nieproporcjonalnie wielkiej ilości słów, użytych na wyrażenie najprostszej choćby myśli. Chrościński użył do przekładu formy oktawy, formy trudnej i wymagającej od twórcy wielkiej kultury artystycznej i wyrobionego smaku, a więc zalet, jakich darmo szukać w Polsce u schyłku XVII w. Z góry tedy wolno się spodziewać, że wybór ten

${ }^{\text {I2 } 2}$ P. Chmielowski, Krytyczno-porównawczy przeglad dziejów piśmiennictwa polskiego, Warszawa 1905, s. 113.

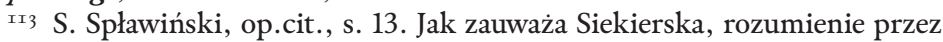
Spławińskiego wyrazu „napuszony” w znaczeniu współczesnym jako „nadęty, pompatyczny” świadczy o nieznajomości historii języka. „U Chrościńskiego oznacza on tyle, co «natchniony, przepojony duchem», por. np. cytat: «Często szaleją, jako bliskie Idy Pod czas mięsopust czynią Eneidy kiedy je Bachus swym napuszy duchem» - albo: «Gdy się kadukiem wieszczym napuszyła Siostra ma, zawsze Kassandra wróżyła» (Rezmowy listowne [...], s. 43, 243)”. K. Siekierska, Zapomniany poeta - Wojciech Stanistaw Chrościński, s. 135. 
będzie niefortunny. Tłumacz rozwadnia dla rymu treść oryginału, który sam przez się nie grzeszy zbytnią zwięzłością wyrazu; na przekładzie zaciążyło to fatalnie. Charakterystyczna dla przeżywającego się już baroku gadatliwość jest jedną z najznamienniejszych cech przekładu ${ }^{\mathrm{II}}$.

Pozytywną ocenę, zachęcającą do badań spuścizny tłumacza Pharsalii, formułuje odkrywca i edytor wielu tekstów dawnych, „prawdziwy Kolumb literatury staropolskiej”, jak go określa Krzysztof Mrowcewicz ${ }^{\mathrm{II}}$, Aleksander Brückner, który twierdzi:

Chrościński zasługuje ze wszech miar na bliższe zbadanie swej spuścizny literackiej, przewyższając i stylem i liczbą prac i ich rozmaitością współczesnych pisarzy, Ustrzyckiego, Bardzińskiego, Wadowskiego i innych, kończąc godnie szereg, w którym błyszczą imiona Twardowskiego i Potockiego ${ }^{\mathrm{II} 6}$.

Charakteryzując zaś w Dziejach literatury pięknej w Polsce poezję czasów saskich, umieszcza Chrościńskiego w rozdziale Pisarze celniejsi ${ }^{1 \mp}$.

Nie znaczy to jednak, że Brückner jest wobec spuścizny Chrościńskiego bezkrytyczny. Już sam kontekst, w którym sytuuje autora Joba cierpiacego..., jest bardzo wymowny. Pisze bowiem: „Dla zupełności należy jeszcze scharakteryzować pokrótce kilka miernot, wystających nieco ponad niskim poziomem spółczesnym. Najwyżej ceniono W. Chrościńskiego, co ze szkoły Potockiego i Lubomirskiego wyszedłszy, przeważnie tylko thumaczył" "ז8 , a nieco dalej, odnosząc się do dzieł autora osnutych na „tematach starozakonnych”, przypisywanych niekiedy Lubomirskiemu, podsumowuje ten wątek w następujących słowach: „sztuka Lubomirskiego stała o wiele wyżej; Chrościński swoją naiwnością zbyt często rozśmiesza tylko, gdzie Lubomir-

${ }^{\text {II } 4}$ Ibidem, s. 15.

II5 K. Mrowcewicz, Palimpsesty Sepowe, w: Corona scientiarum. Studia z bistorii literatury $i$ kultury nowożytnej ofiarowane Profesorowi Januszowi Pelcowi, red. J.A. Chrościcki, J. Gałażewski, M. Prejs, K. Mrowcewicz, Warszawa 2004, s. 61.

Ir6 A. Brückner, [rec.] Chrościński W.St., Lament strapionej ojczyzny..., s. 371. W Geschichte der polnischen Literatur, Leipzig 1901, zawarł Brückner uwagę, że Chrościński był uważany w siedemnastym wieku za największy poetycki talent (s. 204).

${ }^{\text {I17 }}$ A. Brückner, Dzieje literatury pięknej w Polsce, cz. 1, Kraków 1935, s. 301 .

Ir8 Ibidem. 


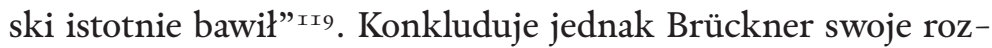
ważania następująco: „Że o autorstwo jego wierszy pomawiano Lubomirskiego i Kochowskiego, jeszcze najwięcej go zaleca" ${ }^{\text {I20 }}$.

O Chrościnskim wspomina Brückner raz jeszcze, kiedy pisze o Tobiaszu Lubomirskiego: „Za Lubomirskim poszedł Wadowski, a jeszcze ściślej Chrościński, tak dalece, że np. Anama [sic! - L.T. ] wydrukowano w XVIII wieku raz jako dzieło Chrościńskiego, drugi raz jako Lubomirskiego: rzecz ta o dziewięciu pieśniach nieco słabszą od Tobiasza się wydaje, mniej w niej ruchu i czucia, może więc nie wyszła z pod pióra wielkiego marszałka” ${ }^{\text {I2I. }}$.

Jednoznacznie negatywną ocenę Chrościńskiego zawiera Wielka Encyklopedia Powszechna Ilustrowana: „wierszopis płodny, lecz mało utalentowany, rozwlekły, prozaiczny, przeważnie był thumaczem lub parafrastą" ${ }^{\text {I22 }}$. Podobną skalę wartościowania wobec przekładów Chrościńskiego przyjmuje w swoich Wyktadach uniwersyteckich Roman Pilat ${ }^{123}$.

Odmiennego zdania jest Wiktor Gomulicki, zdecydowanie oponując przeciwko nazwaniu autora Józefa... przez Piotra Chmielowskiego „nadętą miernością” . „Jest to sąd niesprawiedliwy. Ani talent tego pisarza nie był mierny, ani on sam nadęty" ${ }^{124}$.

Jednakże opinie o braku literackiego talentu Chrościńskiego nie milkną. Tadeusz Myszka, omawiając Trąę wiekopomnej stawy, stwierdza, że całą wyprawę wiedeńską opowiada Chrościński z pozycji naocznego świadka, ,ale bez wdzięku”, a z realiów obozowego życia, toczonych walk i odniesionej chwały „nie dał żadnego rytmu rycerskiego, żadnego ciekawego, podpatrzonego obrazka" ${ }^{25}$. Stanisław Windakiewicz przekład Pharsalii Lukana pióra Chrościńskiego nazywa „niezbyt udanym” ${ }^{226}$.

II9 Ibidem.

ז20 Ibidem.

I2I A. Brückner, Skarby dawnej poezji polskiej, „Biblioteka Warszawska” 1899 , t. 2, s. 417.

I22 Wielka Encyklopedia Powszechna Ilustrowana, t. 9, Warszawa 1893, s. 893. Znajdujemy dalej wzmiankę o tym, że ogłoszony bezimiennie poemat o Józefie przypisany został Chrościńskiemu przez Załuskiego, podczas gdy inni jako autorów dzieła wymieniali S. Szczawińskiego, M. Godlewskiego i S. Starodubowskiego. K. Estreicher (Bibliografia polska, część 3, t. 3 (25), Kraków 1896, s. 216), informując również o bezimiennym wydaniu Józefa, nadmienia zarazem, że „współcześni - Załuski (Bibl. poet. 34) i Jabłonowski (Ostafi, Musaeum s. 38) odsłaniają autora”.

${ }^{\text {I23 }}$ R. Pilat, Historia literatury polskiej. Wyktady uniwersyteckie, t. 3: Historia poezji polskiej od r. 1632-1740, Warszawa 1911, s. 268-269.

${ }^{124}$ W. Gomulicki, op.cit., s. 12.

I25 T. Myszka, Zwycięzca spod Wiednia. Król Jan III Sobieski w literaturze polskiej, „Kurier Literacko-Naukowy” 1933, nr 37, s. III.

ז26 S. Windakiewicz, Poezja ziemiańska, Kraków 1938, s. 151. 
Najsurowszą ocenę wystawia Chrościńskiemu Konstanty Marian Górski, który omawiając Trąę wiekopomnej stawy... pisze expressis verbis:

Niestety, pomieszał on szczyptę wspomnień z ogromną ilością pustych frazesów, prawdę z pseudo-poezją i w niekształtnej tej bryle nie ma już nic, co by nas pociągać mogło. Dziwna, że takiego wierszokletę, wierszoroba otaczała kiedyś taka sława! Musiał to być człowiek pozbawiony zupełnie choćby cienia artystycznej twórczości i wyobraźni ${ }^{127}$.

Główny zarzut, który formułuje wobec autora dzieła, to całkowita nieznajomość „epicznego stylu i toku”, brak epicznej rozległości przedstawianych obrazów oraz indywidualnych rysów ukazywanych bohaterów, co sprawia, że postaci pozostają bez wyrazu, ukazywane są niejako poza głównym tokiem dziejących się zdarzeń, „nie wśród akcji” ${ }^{22}$. Wady dzieła Chrościńskiego prezentuje Górski przez porównanie z utworem Wacława Kochowskiego Dzieto Boskie albo Pieśni Wiednia wybawionego $i$ inszych transakcje wojny tureckiej w r. 1683 szcześliwie rozpoczętej, konkludując rozważania uwagą: „W mniejszym zapewne stopniu, niż u Chrościńskiego, daje się tu czuć brak epicznego tonu, znajomości epickiego traktowania przedmiotu" ${ }^{29}$.

Julian Krzyżanowski wspomina Chrościńskiego, omawiając Psalmodię Wespazjana Kochowskiego. Pisze:

Tendencje, które do szczytu doszły w Psalmodii, szablonowo, lecz szeroko i silnie działały w literaturze drugiej połowy w. XVII, by wydać całe mnóstwo mniej lub więcej rzemieślniczych tomów, niekiedy bardzo znacznej objętości. Dość wskazać na ogromną pracę Wojciecha Stanisława Chrościńskiego, sekretarza królewskiego, który przełożył oktawą Farsalię Lukana (1690), ale nie poprzestał na tym, lecz zaopatrzył ją $\mathrm{w}$ dodatek skompilowany pracowicie „z różnych autorów rzymskie dzieje opisujących”, „nie bawiąc się żadnymi digressjami poetyckimi, jakowe się znajdują w Pharsaliej Lukana" ${ }^{13}$.

I27 K.M. Górski, op.cit., s. 149.

${ }^{\text {I28 }}$ Ibidem, s. 150.

I29 Ibidem.

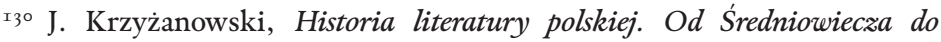
XIX w., Warszawa 1953, s. 380. Stwierdzenia te powtórzy badacz w niezmienionej postaci w pracy Historia literatury polskiej. Alegoryzm - preromantyzm, Warszawa 1964, s. 357. 
W Chrościńskim dostrzega też badacz kontynuatora siedemnastowiecznej poezji religijnej reprezentowanej między innymi przez popularne wówczas mesjady ${ }^{\mathrm{I} 3 \mathrm{I}}$. Dla Krzyżanowskiego twórczość autorów mesjad, „wraz z mnóstwem innych wierszowanych prac treści religijnej pisywanych przez Chrościńskiego, Lubomirskiego oraz przez innych pisarzy o nic nie mówiących nazwiskach, otwiera szeroko wrota zalewowi literatury przez pisma dewocyjne i ascetyczne i w ten sposób inauguruje epokę saską" ${ }^{32}$.

Janusz Pelc, przedstawiając w swojej pracy Jan Kochanowski w tradycjach literatury polskiej galerię trenopisów, którzy podjęli w swojej twórczości naśladownictwo języka, stylu i wzorca konstrukcyjnego cyklu poety z Czarnolasu, wymienia również Chrościńskiego jako autora Trenów żałobnych po śmierci... poświęconych żonie Agnieszce Chrościńskiej i wydanych w roku 1709. Badacz dostrzega znaczne różnice $\mathrm{w}$ stylu wypowiedzi Chrościńskiego $\mathrm{w}$ odniesieniu do Trenów Kochanowskiego, a wszelkie nawiązania do słownictwa pierwowzoru ocenia jako powierzchowne. Język i styl Chrościńskiego jest świadectwem podjęcia wzorów kwiecistej, „nastrzępionej słówki” retoryki czasów baroku, szczególnie modnej w schyłkowej fazie epoki sarmatyzmu ${ }^{\mathrm{I} 33}$. Jako nieudaną ocenia również badacz podjętą przez Chrościńskiego próbę, nawiązującą do stylu wzniosłej tonacji patriotycznej liryki Kochanowskiego, parafrazy horacjańskiej, pod tytułem Ode Polonica ${ }^{\mathrm{I} 34}$.

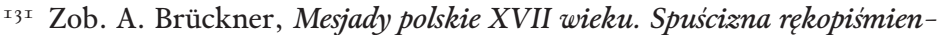
na po Wactawie Potockim, „Rozprawy Akademii Umiejętności Wydział Filologiczny” 1898, cz. 1, t. 27; A. Glazer, „Nowy zaciag” Wactawa Potockiego na tle wybranych mesjad staropolskich, „Prace Literackie” 1981, t. 22, z. 12; A. Gorzkowski, Wizja świata w „Raju utraconym” Jobna Miltona i mesjadzie Szymona Gawtowickiego „Jezus nazareński [...] albo Jeruzalem niebieska przezeń wyzwolona”. (Próba komparatystyki niewplywologicznej), w: Między średniowieczem a renesansem. Kolokwia polsko-włoskie, red. J. Malicki, P. Wilczek, t. 1, Katowice 1994; J.Z. Lichański, Mesjada Wespazjana Kechoweskiego, w: Literatura polskiego baroku w kręgu idei, red. A. Nowicka-Jeżowa, M. Hanusiewicz, A. Karpiński, Lublin 1995; H. Kasprzak-Obrębska, Dwie póżnobarokowe mesjady, w: Literatura a liturgia. Księga referatów międzynarodowej sesji naukowej. Łódź 14-17 maja 1996, red. J. Okoń, M. Kwiek, M. Wichowa, Łódź 1998; L. Teusz, „Bolesna Muza nie Parnasu Góry, ale Golgoty”. Mesjady polskie siedemnastego wieku, Warszawa 2002; A. Rożniatowski, Pamiatka krwawej ofiary Pana Zbawiciela naszego Jezusa Chrystusa, wyd. J.S. Gruchała, Warszawa 2003.

${ }_{{ }^{1} 32}$ J. Krzyżanowski, Historia literatury polskiej. Alegoryzm - preromantyzm, s. 359.

${ }^{1} 33$ J. Pelc, Jan Kochanowski w tradycjach literatury polskiej, Warszawa 1965, s. 188.

${ }{ }_{34}$ Ibidem. 
Wacław Borowy w książce O poezji polskiej wieku XVIII, bardzo krytycznie oceniając literaturę czasów saskich, wśród której,

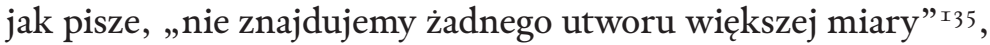
poświęca Chrościńskiemu nieco więcej uwagi, odnajdując jednak w jego twórczości pewne cechy pozytywne. Są nimi według badacza: prostota oraz rzetelność i prawdziwość osobistych uczuć, realizm oraz gorący, głęboki patriotyzm. Prawdziwą siłę poetyckiego słowa dostrzega Borowy szczególnie w Krótkim zbiorze duchownych zabawe, książeczce, która w jego przekonaniu musiała trafić w ducha epoki, ponieważ już po roku nastąiło jej drugie wydanie. Brak barokowych konceptów, rezygnacja z kunsztowności stylu, prostota i autentyczność modlitewnego wyrazu, wszystko to wpływa, według Borowego, na przekonywającą moc słów zamieszczonych w zbiorze religijno-patriotycznych utworów ${ }^{\mathrm{I} 36}$.

W swej fundamentalnej syntezie polskiej literatury barokowej Czesław Hernas przywołuje Chrościńskiego w części trzeciej Późny barok, w rozdziale poświęconym romansowi duchownemu i nowelistyce. Autor wskazuje na proces odradzania się w schyłkowym baroku romansu duchownego, zastępującego stopniowo świeckie, często niemoralne historyje, które nie mogły być drukowane bez aprobaty cenzury, pozostawały więc w rękopisach i tym samym były spychane na margines literatury ${ }^{\mathrm{I}} 37$. Dla romansów biblijnych źródłem inspiracji stawały się fabularne epizody z dziejów biblijnych poddane procesowi narracyjnego, niekiedy bardzo rozbudowanego, toku opowiadania. Obok Tobiasza wyzwolonego Stanisława Herakliusza Lubomirskiego z 1683 roku, niewydanej drukiem Judyty Wacława Potockiego wymienia Hernas właśnie powieści duchowne Chrościńskiego: Joba cierpiacego..., Józefa do Egiptu od braci przedanego oraz Amana..., dostrzegając w nich realizację atrakcyjnej narracji romansowej. Jak zauważa Hernas, Chrościński, ożywiony moralną intencją $\mathrm{w}$ podjęciu pobożnego tematu, nie rezygnował $\mathrm{z}$ ambicji artystycznych, a jako przykład cytuje badacz oktawy przedstawiające scenę kuszenia Józefa przez Putyfarową z Józefa do Egiptu od braci przedanego ${ }^{13}{ }^{8}$. Epizody tego rodzaju, zauważa autor $B a-$ roku, ,niezależnie od ogólnej tendencji dzieła, same w sobie wydawały się moralnie niebezpieczne" ${ }^{339}$, stąd być może wynikały

\footnotetext{
I35 W. Borowy, O poezji polskiej wieku XVIII, Warszawa 1978, s. 17.

${ }^{13}{ }^{6}$ Ibidem, s. 19-20.

I37 C. Hernas, Barok, Warszawa 1980, s. 550.

${ }^{13^{8}}$ Zob. ibidem, s. 552.

I39 Ibidem.
} 
trudności z uzyskaniem aprobaty na druk i ukazanie się utworu, podobnie jak i Amana..., dopiero w roku 1745.

Wśród autorów minorum gentium - świeckich i zakonnych schyłku baroku, różniących sięzarównogenealogią społeczną, jak i charakterem produkowanych tekstów, takich twórców jak: Jan Stanisław Jabłonowski, Piotr Łoski, Adam Warakomski, Dominik Rudnicki, Piotr Kwiatkowski, Hieronim Fałęcki, Karol Mi-

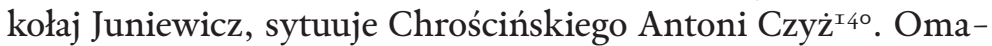
wiając Krótki zbiór duchownych zabare, badacz zwraca uwagę na to, że „zbiór [...] znamiennie odcina się - mocnym i sugestywnie zarysowanym napięciem emocjonalnym - od beznamiętnej twórczości Jabłonowskiego" ${ }^{4}$ I. Liryczny tom Chrościńskiego postrzega Czyż jako dzieło niosące „rzadki pośród popularnej twórczości późnego baroku blask poezji prywatnej poświadczającej odrębność i wartość osoby" ${ }^{{ }^{4} 42}$. Przez mocny, własny, intymny i prywatny ton staje się ono „wyrafinowaną repliką dawnej formy” ${ }^{143}$. Jednak na tle popularnej twórczości późnego baroku

próba Chrościńskiego - ślady śmielszej indywidualności i bardziej radykalnej ekspresyjności wypowiedzi - pozostanie izolowana. Ma to wielorakie owoce. Oznacza bowiem faktyczny rozpad barokowego humanizmu - zespołu poglądów skupionych wokół człowieka przeżywanego jako suwerenny podmiot, jako osoba wobec Boga i jako wartość. Ku takiej postawie - humanistycznej - zmierza bodaj tylko Chrościński ${ }^{\mathrm{I} 44}$.

Marek Prejs charakteryzuje twórczość Chrościńskiego jako „zapatrzenie na wzorce literackie poprzedniego [XVII - L.T.] stulecia” ${ }^{45}$. Autor jawi się badaczowi „,jako wierny uczeń i kon-

I40 A. Czyż, Ja i Bóg. Poezja metafizyczna późnego baroku, Wrocław 1988, s. 43.

I4I Ibidem, s. 51. Przedmiotem porównania są dla Czyża utwory J.S. Jabłonowskiego: Traktacik o Boskiej Opatrzności (Lwów 1727), Męka naszego Pana Jezusa Chrystusa przez modlitwy na każdy dzień całego postu (Lwów 1734) oraz wcześniejsza, odmienna jej wersja Modlitwy na post wielki i na dni jego (Częstochowa 1719), Męka naszego Jezusa Chrystusa przez modlitwy na każdy dzień całego postu (Lwów 1771).

I42 Ibidem, s. 52.

I43 Ibidem.

I44 Ibidem, s. 57. Utwory Chrościńskiego, co powtórzy Czyż w Zakończeniu swoich rozważań o poezji metafizycznej późnego baroku, stanowią przykład poezji „prywatnej” skierowanej ku wnętrzu człowieka, wyraźnie introspekcyjnej, analizującej świat doznań i doświadczeń wewnętrznych (s. 132).

I 45 M. Prejs, Poezja późnego baroku. Główne kierunki przemian, Warszawa 1989, s. 43. 
tynuator literatury dojrzałego baroku" ${ }^{\text {¿46 }}$ szczególnie w podjęciu gatunku „romansu duchownego”, który ma wówczas tak liczne realizacje, oraz $\mathrm{w}$ nawiązaniach do tradycji siedemnastowiecznej poezji religijnej ${ }^{147}$. W późniejszej pracy Konceptyzm czasów saskich - próba ogladu kierunku przemian Prejs umieszcza Chrościńskiego wśród „mniej lub bardziej bezpośrednich” naśladowców Poezji postu świętego Lubomirskiego, takich jak Piotr Franciszek Alojzy Łoski i Michał Serwacy Wiśniowiecki ${ }^{148}$.

Stefan Nieznanowski, podejmując temat obrazu Maryi w poezji polskiego baroku i czasów saskich, przywołuje maryjne utwory Chrościńskiego i stwierdza, że zawierają one „mocny ładunek obroku dusznego" "49 i wpisują się w tak modne ówcześnie, zgodnie $\mathrm{z}$ duchem siedemnastowiecznych rozpraw teologicznych, , wierszowane traktaty mariologiczne" ${ }^{5 \circ}$.

Andrzej Vincenz, wskazując na dokonania wydawnicze, wydobywające na światło dzienne literaturę polskiego baroku, zauważa: „Nadal nie wydane są dzieła co najmniej dziesięciu czołowych poetów, choć można wyliczyć około stu, których przedrukować by warto, a nawet by należało. I jest to z pewno-

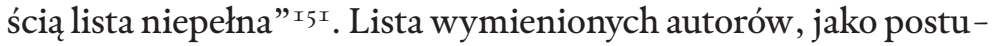
lat, skonfrontowana z późniejszymi edycjami utworów, uległa pewnej zmianie. Jednakże wymienione przez Vincenza nazwisko Chrościńskiego nadal wiąże się z utworami, „które przedrukować by warto".

Hanna Dziechcińska wskazuje na losy dzieła Owidiusza $\mathrm{He}-$ roides sive epistulae w przekładzie Chrościńskiego, wydanego jako Rozmowy listowne, który to utwór (powtarza badaczka opinię Klimowicza): „Wypełnić miał rażącą lukę w literaturze polskiej - brak romansu listowego" ${ }^{522}$. Charakteryzując twórczość niejakiego Aleksandra Pawła Zatorskiego, autora czasów saskich, pisze Dziechcińska o pojawiających się u niego cytatach fragmentów Rozmów listormych. Szczególnym punktem odniesienia staje się Chrościński dla Zatorskiego jako autora pierwszej pol-

${ }^{1} 46$ Ibidem, s. 42.

r47 Ibidem, s. 43.

${ }^{1} 4^{8}$ M. Prejs, Konceptyzm czasów saskich - próba oglądu kierunku przemian, w: Koncept w kulturze staropolskiej, red. L. Ślęk, A. Karpiński, W. Pawlak, Lublin 2005, s. 188.

${ }_{49}$ S. Nieznanowski, Matka Boska w poezji baroku i czasów saskich, w: Studia i wizerunki. O poezji staropolskiej ijej badaczach, Warszawa 1989, s. 49.

${ }^{150}$ Ibidem, s. 46.

${ }^{15}$ A. Vincenz, O opisie stownictwa polskiej poezji barokowej, w: Barok w polskiej kulturze, literaturze i jezzyku. Materiaby z konferencji naukowej 25-29 sierpnia 1987 r. w Krakowie, red. M. Stępień, S. Urbańczyk, Warszawa-Kraków 1992, s. 252.

${ }^{152}$ H. Dziechcińska, op.cit., s. 32, cyt. za: M. Klimowicz, op.cit., s. 415. 
skiej sentymentalnej powieści w listach Przydatek do uwag zupetnemu stanowiacych się szczęściu stużacych etc. Osobliwy, przez tego co i przedtem Podgórzanina Ich Mościow Kazualerów ciekawości i pożytkowi poświęcony, to jest list listów rozlicznych do delikatnej o pozwolona przyjaźń, tomików dwa (tom 1, Kraków 1746, tom 2, 1746, wydanie następne: Wrocław 1760)도. Dostrzec można podobieństwa $\mathrm{w}$ kompozycji obu dzieł, analogie pod względem treści i emocjonalnego stylu wypowiedzi ${ }^{154}$.

Wzajemne zależności pomiędzy Zatorskim a Chrościńskim dostrzegł już wcześniej Klimowicz. Jako szczególny przykład wskazywał właśnie dzieło Zatorskiego Przydatek, będące listownikiem miłosnym, mającym służyć jako wzór kawalerom „do zupełnego stanowiących się szczęścia" ${ }^{55}$. Wykorzystał w nim Zatorski między innymi motto z Rozmów listownych Chrościńskiego:

Pisz, upewniam cię, choć będzie ze stali,

To się wzajemną miłością rozpali ${ }^{156}$.

Przywoływana wielokrotnie Siekierska kończy swoje uwagi o życiu i twórczości Chrościńskiego następującym stwierdzeniem:

Chrościński z pewnością nie był wielkim poetą. Sam zresztą nie uważał się za takiego, stwierdzając skromnie: „Daleko się ja tułam od Parnasu/ Gdzie chor dziesiętny mieszkanie ma swoje" (Trąba, Do czytelnika). Miał jednak wielką swobodę wierszowania, umiejętność podchwytywania obrazków obyczajowych, dużą wrażliwość na ludzka niedolę, wyjątkowo silnie rozwinięte uczucia patriotyczne oraz wierne, namiętne uwielbienie dla króla i jego rodziny. Odznaczał się też dużą kulturą literacką ${ }^{\mathrm{I57}}$.

Zdaniem badaczki, co poświadcza w monografii, twórczość autora Rozmów listowny ch jest też bogatym i cennym źródłem do badań językowych. Przedkładane przez nią opracowanie języka Chrościńskiego w osiągniętych rezultatach jest, w przeświadczeniu badaczki,

\footnotetext{
${ }_{53}$ Por. H. Dziechcińska, op.cit., s. 49.

${ }_{54}$ Ibidem, s. 51.

I55 M. Klimowicz, op.cit., s. 415.

${ }^{15}{ }^{6}$ Ibidem, s. 418.

${ }_{57}$ K. Siekierska, Język Wojciecha Stanistawa Cbrościńskiego, s. 12.
} 
jeszcze jednym głosem sprzeciwu wobec teorii głoszących upadek literatury i języka tego okresu (o ile w ogóle można mówić o upadku języka). Wiek XVII, a w nim i omawiany autor, reprezentuje po prostu nowy etap rozwoju - demokratyzację języka literackiego spowodowaną masową twórczością piśmienniczą ludzi różnych warstw i różnego poziomu kulturalnego. Widać to wyraźnie na przykładzie Chrościńskiego, którego losy życiowe prowadzą od plebejskiej, mieszczańskiej rodziny, poprzez służbę u magnatów, aż na dwór królewski. To społeczne zróżnicowanie środowisk musiało odbić się w języku ${ }^{\mathrm{I}}{ }^{8}$.

W samej zaś konkluzji swoich wywodów Siekierska, po zestawieniu bogatego materiału egzemplifikacyjnego, po dokonaniu szczegółowych analiz i porównań twórczości Chrościńskiego z innymi autorami XVI i XVII wieku, raz jeszcze stwierdza, że nie był on pisarzem, którego język mógł wywrzeć wpływ na literacką polszczyznę. Można, według niej, zauważyć proces odwrotny, to właśnie autor Józefa do Egiptu przedanego... „czerpał obficie z zasobu piśmiennictwa i żywej mowy otaczającego go środowiska” ${ }^{59}$. Twórczość Chrościńskiego zatem, jak zauważa badaczka, dopełnia obrazu bardzo ciekawego z punktu widzenia analiz językoznawczych okresu przejściowego między staropolszczyzną a językiem nowożytnym, kiedy to w materiale językowym da się zauważyć z jednej strony istnienie zjawisk archaicznych, niekiedy wyraźnie już zamierających, z drugiej zaś całą masę zjawisk nowych, rodzących się. Szczególnie bogatym materiałem egzemplifikacyjnym są pod tym względem rękopisy, stosunkowo dokładnie i wiernie oddające żywioł języka mówionego $^{\text {I60 }}$.

Przedstawione, niekiedy tak bardzo rozbieżne, sądy historyków, krytyków i badaczy literatury o twórczości Chrościńskiego, dowodnie przekonują o słuszności wyrażonej kiedyś przez Brücknera (przywołajmy go raz jeszcze) opinii, „iż Chrościński zasługuje ze wszech miar na bliższe zbadanie swej spuścizny literackiej” ${ }^{\text {6I }}$. Dotyczy to szczególnie jego poematów biblijnych,

${ }^{1} 5^{8}$ Ibidem.

I59 Ibidem, s. 334. A. Vincenz (op.cit., s. 256), charakteryzując słownictwo polskiej poezji barokowej, zauważa z kolei: „Inną [...] kategorią są idiosynkrazje poszczególnych autorów, jak np. manieryzm oćma, występujący tylko u Chrościńskiego, od którego zapożyczyło go Oświecenie, a po nim romantyzm”.

ı6о K. Siekierska, Język Wojciecha Stanisława Chrościńskiego, s. 334.

r6r A. Brückner, [rec.] Chrościński W.St., Lament strapionej ojczyzny..., op.cit., s. 371 . 
które, poza nielicznymi wyjątkami (Brückner ${ }^{162}$, Starnawski ${ }^{163}$, Krzysztofik ${ }^{164}$ ), znajdowały się zasadniczo poza oglądem historyków i badaczy literatury.

\section{LESZEK TEUSZ}

\section{Wojciech Stanisław Chrościński (ca. 1660-after 1733) - the man and his work}

The article discusses the figure and the work of the poet from the Saxon times in Poland. The first part of the article presents some essential biographical data and his most important literary achievements - from his debut poem Traba wiekopomnej stawy..., through the translations of the Latin works of Ovid and Lucan, to poems written in the Polish language, such as Biblical poems and other cycles of poems. The other part of the article includes a discussion on the history of the reception of Chrościński's works and the opinions on his literary output given by literary critics and contemporary historians of literature. Diverse and not equivocal opinions emerge - from decidedly favourable to those more restrained and even critical. However, the popularity of the poems written by Chrościński in the seventeenth and the eighteenth centuries is remarkable. This popularity wanes in the course of time and slowly but steadily he becomes an unknown author, rarely recalled and selectively cited. The varied and divergent attitudes of historians of literature make us fully accept the following opinion given by Brückner: "Chrościński highly deserves a closer study of his literary output". Accordingly, the latter postulate is an invitation to a thorough and deepened investigation of the works of the poet.

${ }^{\text {I62 }}$ A. Brückner, Dzieje literatury polskiej w zarysie, t. 1, Warszawa 1903, s. 382-383.

${ }^{163}$ J. Starnawski, Nad tekstem osiemnastowiecznego poematu o Józefie, s. 257-290. Starnawski (s. 259), przywołując kilkuzdaniową charakterystykę utworu dokonaną przez Brücknera i Hernasa, zauważa: „Na tym kończy się nasza wiedza o poemacie, którego autentycznego tekstu nie mamy i o którego poetyckim kształcie nie powiedziano właściwie jeszcze niczego". Badacz, postulując krytyczne wydanie dzieła Chrościńskiego, skupia uwagę na różnicach, które istnieją między edycją drukowaną a rękopisem.

${ }^{164}$ M. Krzysztofik, Tradycja biblijna $i$ czarnoleska w „Jobie cierpiacym” Wojciecha Stanisława Chrościńskiego. Interpretacja pieśni XXV, „Kieleckie Studia Teologiczne” 1997, nr 1, s. 93-101; eadem, Moralny aspekt cierpienia w barokowym przewierszowaniu biblijnej „Ksiegi Hioba” - „Jobie cierpiacym” Wojciecha Stanistawa Chrościńskiego, „Ruch Literacki” 1999, z. 4, s. 457-468; eadem, XVII-wieczne parafrazy wierszowane Starego Testamentu jako przykład literackiej interpretacji biblijnego Stowa, „Kieleckie Studia Teologiczne” 2002, nr 2, s. 365-382; eadem, Od Biblii do literatury (rozdz. Wojciech Stanisław Chrościński „Job cierpiacy”, s. 213-274 oraz Wojciech Stanistaw Chrościński , Treny Hieremiaszowe”, s. 275-308). 
LESZEK TEUSZ - dr, adiunkt w Zakładzie Literatury Staropolskiej i Oświecenia Instytutu Filologii Polskiej UAM. Zajmuje się literaturą staropolską, szczególnie epoki baroku. Autor książki „Bolesna Muza nie Parnasu Góry, ale Golgoty...”. Mesjady polskie XVII stulecia (2002) oraz licznych artykułów publikowanych w książkach zbiorowych i czasopismach literackich, religijnych i kulturalnych. Współautor podręcznika Skarbiec języka, literatury, sztuki (2002; 2. wyd. 2004) dla liceum, wyróżnionego w 2005 roku przez Komisję do Oceny Podręczników Szkolnych Polskiej Akademii Umiejętności. Stypendysta Fritz Thyssen Stiftung oraz kilkukrotny stypendysta Herzog August Bibliothek w Wolfenbüttel (Niemcy).

e-mail: leteusz@wp.pl 